\title{
Carbon and nitrogen recycling during cyanoHABs in dreissenid-invaded and non-invaded US midwestern lakes and reservoirs
}

\author{
Trinity L. Hamilton $[$ Jessica R. Corman • Jeff R. Havig
}

Received: 25 July 2019/Revised: 1 December 2019/Accepted: 7 December 2019/Published online: 27 December 2019

(C) The Author(s) 2019

\begin{abstract}
Lakes and reservoirs play key roles in global carbon cycling, especially as a carbon sink. Enrichment of nutrients in lakes and reservoirs (eutrophication) and rising global temperatures favors the proliferation of bloom-forming cyanobacteria. Harmful blooms of cyanobacteria (cyanoHABs) alter carbon and nutrient cycling in freshwater ecosystems. Some evidence suggests the introduction or establishment of invasive mussel species (i.e., Dreissena spp.) also favor cyanoHAB formation through selective filter feeding, a process through which they may also impact biogeochemical processes including carbon cycling and sequestration. However, few studies have considered the combined effects of invasive mussels and cyanoHABs on carbon and nitrogen cycling in freshwater ecosystems. Here, we examined microbial
\end{abstract}

Handling editor: Manuel Lopes Lima

Electronic supplementary material The online version of this article (https://doi.org/10.1007/s10750-019-04157-1) contains supplementary material, which is available to authorized users.

T. L. Hamilton $(\bowtie)$

Department of Plant and Microbial Biology, University of Minnesota, 218 Cargill Building, St. Paul, MN 55108, USA

e-mail: trinityh@umn.edu

T. L. Hamilton

The BioTechnology Institute, University of Minnesota,

St. Paul, MN, USA 55108 community composition and biogeochemical attributes (including carbon and nitrogen stable isotopes) in eutrophic lakes, reservoirs, and rivers in western Ohio, eastern Indiana, and northern Kentucky during the cyanobacterial bloom period of the summer of 2015. Our samples include both sites impacted by invasive mussels and those where invasive mussels have not yet been observed. Based on $16 \mathrm{~S}$ and $18 \mathrm{~S}$ rRNA gene sequence analysis, we found that cyanobacterial and algal communities varied across sites and were most closely related to habitat (sediment or water column sample) and site, regardless of the presence of invasive mussels or other environmental factors. However, we did find evidence that invasive mussels may influence both carbon and nitrogen cycling. While the results are based on a single time point sampling, they highlight the interactions of multiple environmental stressors in aquatic ecosystems and the critical need for more temporally intensive studies of carbon and nutrient cycling in bloom- and mussel-impacted waters.

\footnotetext{
J. R. Corman

School of Natural Resources, University of Nebraska, Lincoln, NE 68583, USA

e-mail: jcorman3@unl.edu

J. R. Havig

Department of Earth and Environmental Sciences,

University of Minnesota, Minneapolis, MN 55455, USA

e-mail: jhavig@umn.edu
} 
Keywords Cyanobacteria - Blooms - Carbon stable isotopes - Carbon · Nitrogen - Biogeochemical cycling · Eutrophication - Invasive mussel species · cyanoHABs

\section{Introduction}

Nutrient enrichment, a leading cause of eutrophication in freshwater ecosystems, leads to the proliferation of noxious, and sometimes toxic bloom-forming cyanobacteria (Fogg, 1969; Huisman et al., 2005; Paerl \& Fulton, 2006). CyanoHABs negatively impact water quality by reducing visibility, creating hypoxic zones, and decreasing aquatic biodiversity (e.g., Seehausen et al., 1997; Abrantes et al., 2006; Smith \& Schindler, 2009). In eutrophic lakes, genera of cyanobacteria including Microcystis, Planktothrix, Dolichospermum (formerly Anabaena), Aphanizomenon, Anabaenopsis, and Cylindrospermopsis exploit nutrient enrichment coupled to elevated temperatures and thus are common constituents of summer cyanoHABs. Members of these genera also produce toxins such as microcystin, cylindrospermopsin, saxitoxin, and anatoxin that can sicken humans, and kill pets, fish, birds, and other aquatic biota. The introduction of invasive mussel species (i.e., Dreissena polymorpha, or Zebra mussel, and Dreissena bugensis, or Quagga mussel) can further compound the proliferation of bloom-forming cyanobacteria through selective consumption (Vanderploeg et al., 2001) and nutrient excretion (Arnott \& Vanni, 1996; Conroy et al., 2005; Sarnelle et al., 2005).

Increasing primary productivity due to the occurrence of cyanoHABs and eutrophication alters nutrient cycling (Alexander et al., 2017) and leads to an increase in carbon burial in lakes and reservoirs (Heathcote \& Downing, 2012; Heathcote et al., 2015; Huang et al., 2018). Similarly, the presence of invasive mussels also alters biogeochemical cycling (Higgins \& Vander Zanden, 2010; Williamson \& Ozersky, 2019). Climate change, including warming temperatures and increased hydrologic variability, is expected to increase the growth and dominance of cyanoHABs (Paerl, 2017). However, it is not clear how the spread of non-native mussels will impact eutrophication,
cyanoHAB proliferation, biogeochemical cycling, and ultimately, carbon burial in lakes and reservoirs.

Non-native mussel species (i.e., Zebra and Quagga mussels) have been spreading into aquatic ecosystems across North America since their first appearance in 1988, yet much remains unknown about their longterm ecological effects (Strayer, 2009). As filter feeders, invasive non-native mussel species may improve water clarity and increase the depth of light penetration and have been linked to an increase in the productivity of toxin-producing cyanobacteria (Hecky et al., 2004), and an increase in M. aeruginosa biomass (Vanderploeg et al., 2002; Sarnelle et al., 2005). Mussels can also recycle nutrients contained in microbial biomass back into the water column (Kovalenko et al., 2017). All of these characteristics may assist the establishment and proliferation bloomforming cyanobacteria. For instance, in Lake Erie, mussels exhibited selective rejection of toxin-forming $M$. aeruginosa strains during normal filter feeding, and M. aeruginosa was not abundant in Saginaw Bay (Lake Huron) but became abundant after mussel establishment (Vanderploeg et al., 2001). In contrast, research from a eutrophic lake in Sweden suggests zebra mussels may promote lake recovery from eutrophication through nutrient removal (Goedkoop et al., 2011). Furthermore, an increase in phosphorus loading in the presence of invasive mussels may decrease the abundance of Microcystis spp. (Sarnelle et al., 2012). Clearly, the effects of invasive mussels on cyanoHABs warrant further study.

Carbon in natural systems exists in many different forms including dissolved inorganic, dissolved organic, and particulate organic carbon (DIC, DOC, POC, respectively). The cycling of carbon between DIC, DOC, and POC pools is predominantly biologically mediated. Carbon can also be degraded through photochemistry (Ward \& Cory, 2016). These biotic and abiotic processes impart changes in the isotope signature of carbon. The concentration and carbon isotope signal of this material integrates all of the processes that influence the movement of carbon through the water column and deposition as sediments (as well as movement of carbon from sediments back into the water column). Nitrogen isotopes in eutrophic systems can provide insight into nitrogen sources and nitrogen cycling: nitrogen can be introduced to lakes through natural processes such as in situ biological nitrogen fixation (resulting in biomass with $\delta^{15} \mathrm{~N}$ 
values near $0 \%$, the value of atmospheric air), input of allochthonous sources such as artificial fertilizer (also having $\delta^{15} \mathrm{~N}$ values near $0 \%$ ), or organic material such as plant matter and soil (contributing fixed $\mathrm{N}$ that tends to have $\delta^{15} \mathrm{~N}$ values that are more positive). Degradation of biomass in situ can also contribute to fixed N, including the regeneration of ammonium (Hampel et al., 2019a). Nitrogen cycling and loss via breakdown of organic material and subsequent denitrification results in residual $\delta^{15} \mathrm{~N}$ values becoming more positive (e.g., Wada et al., 1975; Mariotti et al., 1981).

In this paper, we determine community composition of planktonic and sediment microbes across a range of eutrophic lakes and reservoirs and a subset of their tributaries and use stable carbon and nitrogen isotopes to examine biogeochemical cycling in these ecosystems. We focus on select aquatic ecosystems with known mussel presence or absence that have been impacted by cyanobacterial blooms in Ohio, Indiana, and Kentucky, including portions of Lake Erie. Among these sites, Lake Erie has received considerable attention with respect to the impacts and mitigation of cyanoHABs while little to no data exist on bloom community composition or biogeochemical cycling in the others. Finally, we combine these data to develop a framework for assessing the impacts of invasive mussels on biogeochemical cycling in systems impacted by harmful cyanobacterial blooms. We acknowledge the simplification of our conceptual model and limitations of our single time point sampling. Regardless, our data suggest that, in addition to their potential in the potential proliferation of cyanoHABs, invasive mussels should also be considered in carbon cycling dynamics on short- and longterm timescales in eutrophic ecosystems.

\section{Materials and methods}

\section{Sampling strategy}

We sampled reservoirs, rivers, and Lake Erie ranging geographically from Lake Erie in the north to the Ohio River in the south and from Brookville Lake, Indiana in the west to Buckeye Lake, Ohio in the east. Sites were selected to represent ecosystems impacted by cyanoHABs only (Buckeye Lake, Grand Lake St. Marys, Kiser Lake) and by both cyanoHABs and invasive mussel species (Brookville Lake and Lake Erie). We also sampled major rivers (e.g., Auglaize, Maumee, Sandusky, Ohio) to provide a background geochemistry signal representative of mixed groundwater and surface runoff that is feeding the lakes and reservoirs. All sites were sampled in the summer of 2015 during the eutrophically induced cyanobacterial bloom period.

\section{Site Descriptions}

\section{Reservoirs}

Four reservoirs were sampled for water column to sediment depth profiles, including three in Western Ohio (Grand Lake St. Marys, Buckeye Lake, and Kiser Lake) and one in Eastern Indiana (Brookville Lake) (Fig. 1). Grand Lake, or Grand Lake St. Marys (GLSM), is a large $\left(58.3 \mathrm{~km}^{2}\right)$ reservoir in central western Ohio that was created in the early nineteenth century as a feeder for the canal system that connected Lake Erie with the Ohio River, with the deepest point of a little over $3 \mathrm{~m}$. Buckeye Lake is a large reservoir $\left(12.9 \mathrm{~km}^{2}\right)$ in central Ohio that was also created as a feeder for the canal system, converting what was a swamp/bog into a shallow lake (maximum depth of around $4.3 \mathrm{~m}$, but most of the lake is 1.2 to $2.5 \mathrm{~m}$ deep). Kiser Lake is a smaller reservoir $\left(1.6 \mathrm{~km}^{2}\right)$ created when a dam was built in 1939 between moraine deposits, and has a maximum depth of $3.7 \mathrm{~m}$. Brookville Lake is a large reservoir $\left(21.3 \mathrm{~km}^{2}\right)$ in southeastern Indiana which was created as a result of the building of an earthen dam for flood control of the Whitewater River in 1974 by the US Army Corps of Engineers, with the deepest part of the lake $(\sim 36 \mathrm{~m})$ at the base of the dam.

GLSM, Buckeye Lake, and Kiser Lake experience CyanoHABs due to eutrophication blooms. Zebra or quagga mussels have not been reported in these sites (USGS website as of September 2015; https://nas.er. usgs.gov/viewer/omap.aspx?SpeciesID=5). Brookville Lake experiences CyanoHABs and the presence of invasive mussel species has been reported (USGS website as of September 2015; https://nas.er.usgs.gov/ viewer/omap.aspx?SpeciesID=5). At the time of sampling, fresh fish kills were observed at Brookville Lake, GLSM, Kiser Lake, and Buckeye Lake, likely due either to toxins produced by cyanobacteria or anoxic water conditions. Lake surface areas, average depths, and maximum depths are reported in the Supplementary Online Material (Table S1). 


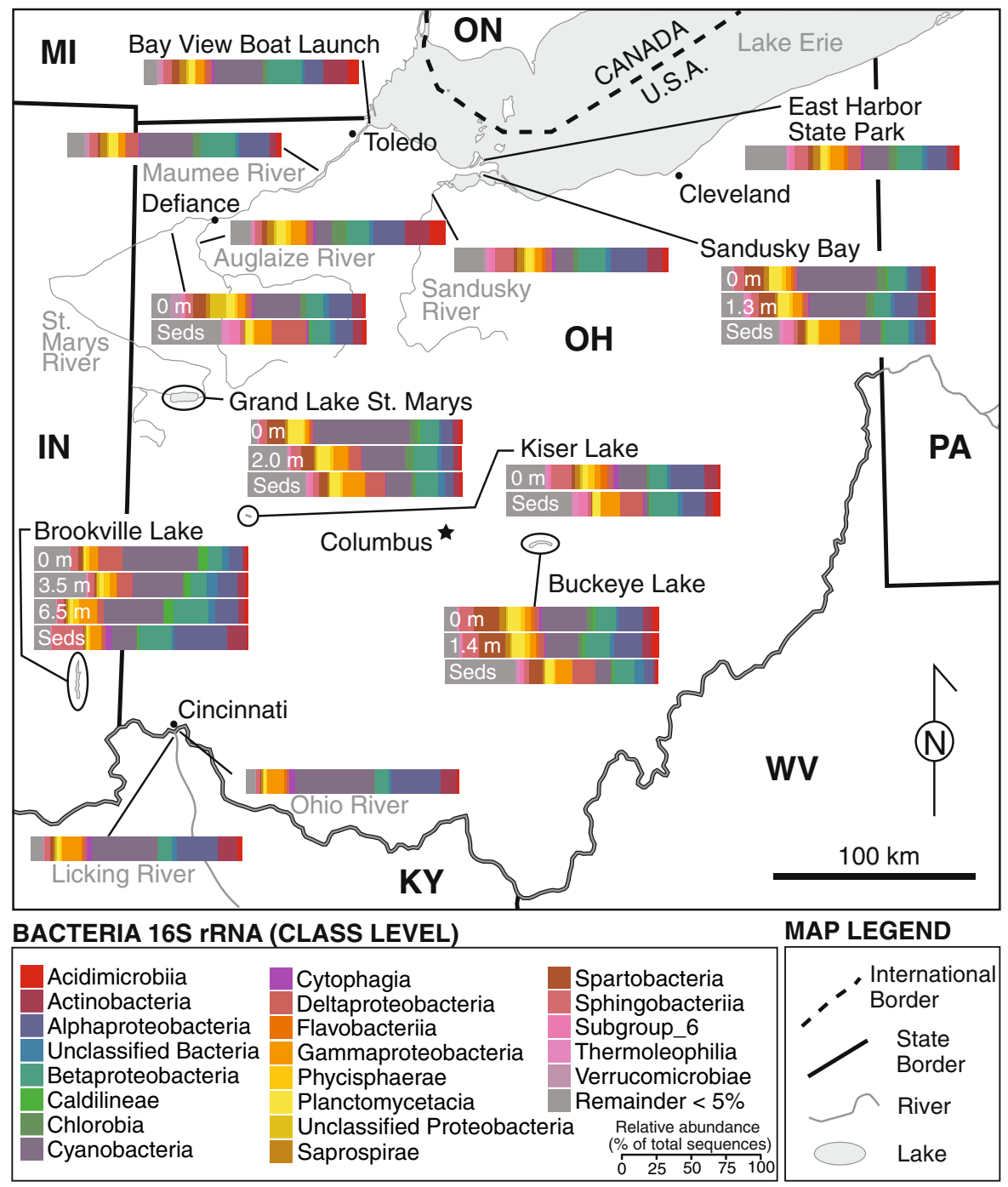

Fig. 1 Composition of 16S rRNA gene sequences recovered from sediment and planktonic biomass in reservoirs, rivers, and lakes in Indiana, Ohio, and Kentucky. Representative OTUs for each library were binned at the Class level. Sample collection

\section{Lake Erie sites}

Three sites were sampled along the southwestern shore of Lake Erie (Fig. 1): Bay View Park, located where the Maumee River empties into Maumee Bay on the far west end of Lake Erie, East Harbor State Park, located on the Lake Erie side of the Marblehead Peninsula which separates it from Sandusky Bay, and Sandusky Bay, a $\sim 77 \mathrm{~km}^{2}$ bay located where the Sandusky River empties into the southern shore of Lake Erie. Lake Erie experiences harmful depths are indicated when more than just the surface was collected. Seds sediments collected at the water-sediment interface

cyanobacterial blooms due to eutrophication and invasive mussel species have been observed at all sites (USGS website as of September 2015; https:// nas.er.usgs.gov/viewer/omap.aspx?SpeciesID=5)

\section{Rivers}

The Auglaize, Maumee, and Sandusky Rivers all feed into Lake Erie. The Auglaize River joins the Maumee River in Defiance, Ohio, and the Maumee River feeds into the western Basin of Lake Erie near Toledo, Ohio. 
We sampled the Maumee and Auglaize Rivers upstream from Defiance, Ohio, and the Maumee River below Defiance (Fig. 1). The Sandusky River flows north into Lake Erie at Sandusky Bay, west of Cleveland. We sampled the Sandusky River where it flows through Fremont, Ohio (Fig. 1). The Ohio River originates in the Appalachian Mountains and flows west from Pennsylvania, forming the border between West Virginia and Kentucky on the south and Ohio and Indiana on the north before emptying into the Mississippi River. The Licking River flows north from Kentucky and empties into the Ohio River near Cincinnati, Ohio. We sampled both the Ohio River and the mouth of the Licking River near Cincinnati (Fig. 1). All of the rivers sampled experience eutrophically induced cyanobacterial blooms and have had reports of invasive mussel species present (USGS website as of September 2015; https://nas.er.usgs.gov/ viewer/omap.aspx?SpeciesID=5).

\section{Sample collection}

Water depth, temperature, conductivity, and oxidation-reduction potential (ORP) were measured in situ using a calibrated multiparameter ProDSS sonde (Yellow Springs, OH, USA). Water clarity was measured using a Secchi disk and is reported as Secchi depth. Water column samples for aqueous geochemistry, nucleic acid extraction, and $\delta^{13} \mathrm{C}$ and $\delta^{15} \mathrm{~N}$ determination were collected with a $3.81 \mathrm{Van}$ Dorn bottle. Approximately $60 \mathrm{ml}$ of water was filtered with a sterile syringe through pre-combusted $\left(12 \mathrm{~h}, 450^{\circ} \mathrm{C}\right) \mathrm{GF} / \mathrm{F}$ filters $(0.3 \mu \mathrm{M}$ pore size) (Sterlitech Corporation, Kent, WA) for each analysis. Filters were immediately frozen on dry ice and stored at $-20^{\circ} \mathrm{C}$ until nucleic acid extraction or $\delta^{13} \mathrm{C}$ and $\delta^{15} \mathrm{~N}$ determination. Sediment samples were collected from the sediment-water interface and immediately frozen on dry ice and stored at $-20^{\circ} \mathrm{C}$ until nucleic acid extraction or $\delta^{13} \mathrm{C}$ and $\delta^{15} \mathrm{~N}$ determination. Samples for ion chromatography analysis of major cations and anions were filtered through 25-mmdiameter, $0.22-\mu \mathrm{m}$ polyethersulfone syringe filters (VWR International, Radnor, PA) into 15-ml centrifuge tubes that had been pre-soaked in $18.2 \mathrm{M} \Omega / \mathrm{cm}$ DI water, and stored at $4^{\circ} \mathrm{C}$ until analysis. Samples for trace element (e.g., Fe, Mn, P) analysis $(10 \mathrm{ml})$ were filtered through a 25-mm-diameter, $0.22-\mu \mathrm{m}$ polyethersulfone syringe filters (VWR International,
Radnor, PA) into acid washed $15-\mathrm{ml}$ centrifuge tubes and acidified with $200 \mu$ l of concentrated OmniTrace Ultra $^{\mathrm{TM}}$ concentrated nitric acid (EMD Millipore, Billerica, MA), and stored at $4^{\circ} \mathrm{C}$ until analysis. Samples for dissolved organic carbon (DOC) concentration and $\delta^{13} \mathrm{C}$ analysis were filtered through $25-\mathrm{mm}$ diameter, $0.22-\mu \mathrm{m}$ polyethersulfone syringe filters into 50-ml centrifuge tubes (final volume $25-30 \mathrm{ml}$ ), flash frozen on dry ice, and stored at $-20^{\circ} \mathrm{C}$ until analysis.

The Van Dorn bottle and all sampling equipment were cleaned with a $70 \%$ ethanol solution between each sampling site to minimize cross contamination. Surface sediment samples (top $\sim 2 \mathrm{~cm}$ ) were collected with a weighted scoop sampler and placed in 50-ml centrifuge tubes with no head space and kept on ice until returned to the lab where they were kept at $4^{\circ} \mathrm{C}$ until processed. Approximately, $20 \mathrm{ml}$ of sample was flushed through the filter before the trace element sample was collected.

\section{Nucleic acid extraction}

DNA was extracted from filters or the sediments using a MoBio PowerSoil ${ }^{\circledR}$ DNA Isolation Kit (MoBio, Carlsbad, CA) according to the manufacturer's instructions. The concentration of DNA was determined using a Qubit dsDNA HS Assay kit (Molecular Probes, Eugene, OR, USA) and a Qubit 3.0 Fluorometer (Invitrogen, Carlsbad, CA, USA), respectively.

\section{$16 S$ and $18 S$ rRNA sequence analysis: community composition and diversity}

Total DNA was submitted to the University of Minnesota Genomics Center (UMGC) where amplicons were sequenced using MiSeq Illumina $2 \times 300$ bp chemistry. Primers 515Ff and $806 \mathrm{rB}$ were employed to target V4 hypervariable region of bacterial and archaeal 16S SSU rRNA gene sequences (Caporaso et al., 2012; Apprill et al., 2015). Primers E572F and E1009 were employed to target the V4 hypervariable region of eukaryotic $18 \mathrm{~S}$ SSU rRNA gene sequences (Comeau et al., 2011). Mothur (ver. 1.40.4; (Schloss et al., 2009) was used for postsequencing processing following the MiSeq SOP (Kozich et al., 2013). Read pairs were assembled and resulting contigs with ambiguous bases were 
removed. Contigs were trimmed to include only the overlapping regions and unique sequences were aligned against the Silva v132 database. Chimeras were identified and removed using UCHIME (Edgar et al., 2011) and removed. Sequences were classified using the TaxAss pipeline (https://github.com/ McMahonLab/TaxAss; Rohwer et al., 2018) using the FreshTrain18Aug2016 database and the Silva database (v132). For bacteria and archaea, operational taxonomic units (OTUs) were assigned to all classified sequences at $97.0 \%$ using the average-neighbor algorithm. For eukarya, OTUs were assigned at $98 \%$ operational using the average-neighbor algorithm. Rarefaction was calculated within mothur and indicated the majority of predicted $16 \mathrm{~S}$ rRNA and $18 \mathrm{~S}$ rRNA gene diversity was sampled at this depth of sequencing (data not shown). All statistical analyses were carried out in $\mathrm{R}$ version 3.4.3 ( $\mathrm{R}$ Core Team, 2018). Ordination analyses were performed using the R software packages vegan (Oksanen et al., 2019) or Phyloseq (ver. 1.16.2; McMurdie \& Holmes, 2013). Differences in alpha diversity metrics were using Mann-Whitney pairwise comparison test. A hierarchical cluster analysis was applied to estimate community similarity in the 16S rRNA data using BrayCurtis dissimilarity and Ward clustering with 1,000 resamplings. Core microbiome of $16 \mathrm{~S}$ rRNA sequences across samples was assessed using MicrobiomeAnalyst (Dhariwal et al., 2017) at a sample prevalence of $25 \%$ and a relative sequence abundance of $5 \%$. Results are reported at the Class and Order level. Prior to ordination, samples were rarefied to even sequencing depth of 9227 (the smallest library in the data set). Differences in $16 \mathrm{~S}$ and $18 \mathrm{~S}$ rRNA community compositions were visualized using nonmetric multidimensional scaling (NMDS) ordination using Bray-Curtis dissimilarities. Unconstrained principal component analyses were performed on the rarified 16S rRNA amplicon libraries using BrayCurtis dissimilarities. A constrained ordination was performed to examine how environmental variables are associated with community composition, also using Bray-Curtis dissimilarities. Significant differences in the NMDS and constrained ordination analyses were evaluated using analysis of similarity permutational multivariate analysis of variance (PERMANOVA). The raw sequencing reads have been deposited at the NCBI Short Read Archive under BioProject ID PRJNA386694 and accession numbers
SAMN07125357 to SAMN07125385. Library designations are provided in Table $\mathrm{S} 2$.

qPCR

Quantitative PCR (qPCR) was used to estimate the number of archaeal and bacterial 16S rRNA gene sequences and 18S rRNA gene sequences in genomic DNA as described previously (Hamilton et al., 2013). Assays were performed in triplicate in a StepOnePlus ${ }^{\circledR}$ (Life Technologies) with the SsoFast EvaGreen Supermix qPCR kit (Bio-Rad Laboratories, Hercules, CA). As described previously, for quantification of archaeal and bacterial 16S rRNA genes, primers 344F (5'-ACGGGGYGCAGCAGGCGCGA-3') and 915R $\left(5^{\prime}\right.$-GTGCTCCCCCGCCAATTCCT- $\left.3^{\prime}\right)$ and $1100 \mathrm{~F}$ $\left(5^{\prime}\right.$-YAACGAGCGCAACCC-3') and 1492R (5'GGTTACCTTGTTACGACTT- $3^{\prime}$ ) were employed at an annealing temperature of $61^{\circ} \mathrm{C}$ or $55^{\circ} \mathrm{C}$, respectively (Hamilton et al., 2013). Primers targeting the V3-V4 region of the cyanobacterial 16S rRNA gene for (Cya359F (5'-GGGGAATYTTCCGCAATGGG$\left.3^{\prime}\right)$ and Cya781R (5'-GACTACWGGGGTATCTAATCCCWTT-'3)) (Nübel et al., 1997) were employed to quantify cyanobacterial $16 \mathrm{~S}$ rRNA gene. Assays were performed at $64^{\circ} \mathrm{C}$ as described previously (Zhang et al., 2014). Primers for quantification for 18S rRNA were the same as those described above for amplicon sequencing and assays were performed at an annealing temperature of $42^{\circ} \mathrm{C}$. For each set of primers, $\sim 1 \mathrm{ng}$ of purified genomic DNA was subjected to qPCR with the following qPCR cycling conditions: initial denaturation $\left(95^{\circ} \mathrm{C}\right.$ for $\left.10 \mathrm{~min}\right)$ followed by 40 cycles of denaturation $\left(95^{\circ} \mathrm{C}\right.$ for $\left.10 \mathrm{~s}\right)$, annealing (at the optimal annealing temperature for each primer as described above for $10 \mathrm{~s}$ ), and extension $\left(72^{\circ} \mathrm{C}\right.$ for $\left.20 \mathrm{~s}\right)$. The standard curves were constructed using $16 \mathrm{~S}$ and $18 \mathrm{~S}$ rRNA sequences from environmental DNA. Genes were amplified from several samples (amplification, PCR conditions, and primers followed those described above), purified using a QIAquick PCR Purification Kit (Qiagen, Carlsbad, CA, USA), and inserted into a pGEM-T easy vector (Promega, Madison, WI) and transformed into JM109 High Efficiency Competent Cells (Promega, Madison, WI). Plasmids were isolated using a Wizard $^{\circledR}$ Plus SV Minipreps DNA Purification System (Promega, Madison, WI) and concentration was measured using a qubit as described above. The copy 
number of each gene was normalized by the concentration of DNA and the grams of sediment (wet weight) used in the DNA extraction.

\section{Aqueous geochemistry}

Major cations (e.g., sodium, potassium, calcium, magnesium) and anions (e.g., chloride, sulfate, nitrate) were determined using a Dionex Liquid ion chromatograph by the STAR Lab at Ohio State University. Trace metal and phosphorus analysis was conducted via Prodigy Dual View Inductively Coupled Plasma Spectrophotometer by the STAR Lab at Ohio State University. Phosphorus represents that $\mathrm{P}$ detected in the $0.22 \mu \mathrm{m}$ filtered portion of the water (detection limit $=0.52 \mu \mathrm{mol} / \mathrm{l})$. Samples for $\mathrm{P}$ were not digested prior to analyses. Total ammonium $\left(\mathrm{NH}_{4}(\mathrm{~T})=\mathrm{NH}_{3}\right.$ $+\mathrm{NH}_{4}{ }^{+}$) was determined using a DR1900 portable spectrophotometer (Hach Company, Loveland, CO). Porewater samples were diluted with 18.2 $\mathrm{M} \Omega / \mathrm{cm}$ DI water prior to spectrophotometric analyses. Samples for dissolved inorganic carbon (DIC) concentration and $\delta^{13} \mathrm{C}$ analysis were filtered through a 25 -mm-diameter, $0.22-\mu \mathrm{m}$ polyethersulfone syringe filters (VWR International, Radnor, PA) into pre-muffled 10-ml glass scintillation bottles (baked at $480^{\circ} \mathrm{C}$ for $8 \mathrm{~h}$ ) that were aluminum-crimp-sealed with silicon-coated gray butyl rubber three-legged lyophilization septa and kept inverted and refrigerated until analysis.

\section{Dissolved carbon}

DIC concentration and $\delta^{13} \mathrm{C}$ analysis were conducted by the Stable Isotope Facility at the University of California, Davis using a GasBench II system interfaced to a Delta V Plus isotope ratio mass spectrometer (IR-MS) (Thermo Scientific, Bremen, Germany) as previously described (Havig et al., 2017). Raw delta values converted to final using laboratory standards (lithium carbonate, $\delta^{13} \mathrm{C}=-46.6 \%$ and a deep seawater, $\delta^{13} \mathrm{C}=+0.8 \%$ ) calibrated against standards NBS-19 and L-SVEC.

DOC concentration and $\delta^{13} \mathrm{C}$ analysis were conducted by the Stable Isotope Facility at the University of California, Davis via an O.I. Analytical Model 1030 TOC Analyzer (O.I. Analytical, College Station, TX) interfaced to a PDZ Europa 20-20 isotope ratio mass spectrometer (Sercon Ltd., Cheshire, UK) utilizing a
GD-100 Gas Trap Interface (Graden Instruments, Ontario, Canada) for concentration and isotope ratio determination as previously described (Havig et al., 2017). Raw delta values converted to final using laboratory standards (KHP and cane sucrose) calibrated against USGS-40, USGS-41, and IAEA-600. The limit of quantification and analytical precision is $0.4 \%$ for $\delta^{13} \mathrm{C}$ of DOC at DOC concentrations greater than $0.5 \mathrm{ppm}$.

\section{Solid sample isotopes}

For $\delta^{13} \mathrm{C}$ and $\delta^{15} \mathrm{~N}$ determination, sediment samples and filtered water column biomass samples were treated as described previously (Schuler et al., 2017). Briefly, they were dried at $60^{\circ} \mathrm{C}$ for 3 days. Prior to drying, sediment samples were weighed. Dried sediment samples were weighed, homogenized with a clean mortar and pestle (pre-scoured using an $80 \%$ ethanol-silica sand slurry, then rinsed with 18.2 M $/$ $\mathrm{cm}$ deionized water). For organic carbon $\delta^{13} \mathrm{C}$ determination, dried and ground sediments were decarbonated: a subset of each sediment sample was weighed, soaked in $1 \mathrm{M} \mathrm{HCl}$ for $24 \mathrm{~h}$, washed with $18.2 \mathrm{M} \Omega /$ $\mathrm{cm}$ deionized water three times to remove excess $\mathrm{HCl}$, dried at $60^{\circ} \mathrm{C}$ for 3 days, weighed, and homogenized with a clean mortar and pestle. Filtered biomass decarbonation was carried out via flushing with $1 \mathrm{M}$ $\mathrm{HCl}$ followed by rinsing with $18.2 \mathrm{M} \Omega / \mathrm{cm}$ deionized water. Sediment and filtered samples for $\delta^{15} \mathrm{~N}$ determination were not subject to decarbonation. Filters or sediments were then placed into tin boats and analyzed using a Costech Instruments Elemental Analyzer (EA) periphery connected to a Thermo Scientific Delta V Advantage Isotope Ratio Mass Spectrometer (IR-MS) located in the Department of Geology at the University of Cincinnati as described previously (Havig et al., 2017). Linearity corrections were made using NIST Standard 2710, and $\delta^{13} \mathrm{C}$ values were calibrated using reference standards USGS-40 and USGS-41 and checked with a laboratory standard (glycine).

All stable carbon isotope results are given in delta formation expressed as per mil (\%o):

$\left.\delta^{13} \mathrm{C}=\left[\left(R_{\mathrm{a}}\right)_{\text {sample }} /\left(R_{\mathrm{a}}\right)_{\text {standard }}\right)-1\right] \times 10^{3}$,

where $R_{\mathrm{a}}$ is the ${ }^{13} \mathrm{C} /{ }^{12} \mathrm{C}$ ratio of the sample or standard, and are reported versus the Vienna Pee Dee Belemnite (VPDB) standard. All stable nitrogen results are given 
in the same delta notation as described above $\left(\delta^{15} \mathrm{~N}\right.$, expressed in \%o), where $R_{\mathrm{a}}$ is the ${ }^{15} \mathrm{~N} /{ }^{14} \mathrm{~N}$ ratio of the sample or standard, and the results are reported versus air.

\section{Biogeochemical model}

As an exercise for comparison of the sampling sites, we estimated the fraction DIC removed as organic carbon from these systems using an equation for estimating the fraction of organic carbon removed from the global ocean system:

$\delta^{13} \mathrm{C}_{\text {DIC }}=\delta^{13} \mathrm{C}_{\text {source }}+F_{\text {org }}\left(\Delta_{\mathrm{C}}\right)$,

Solved for $F_{\text {org }}$ as

$F_{\text {org }}=\left(\delta^{13} \mathrm{C}_{\text {DIC }}-\delta^{13} C_{\text {source }}\right) / \Delta_{\mathrm{C}}$,

where $\delta^{13} \mathrm{C}_{\text {DIC }}$ is the $\delta^{13} \mathrm{C}$ value of DIC, $\delta^{13} \mathrm{C}_{\text {source }}$ is the $\delta^{13} \mathrm{C}$ value of the source for the DIC, $F_{\text {org }}$ is the fraction of DIC removed as organic carbon through fixation, and $\Delta_{C}$ is the fractionation factor imposed by photosynthetic fixation of DIC into organic carbon. As the $\delta^{13} \mathrm{C}_{\text {source }}$ is approximated by either atmospheric $\mathrm{CO}_{2}$ or the river DIC value, we incorporate both values into the equation to calculate a potential range for $F_{\text {org }}$. We assume that the $\Delta_{\mathrm{C}}$ is approximated by the $\delta^{13} \mathrm{C}$ value of seston organic carbon minus the $\delta^{13} \mathrm{C}$ value of DIC for the surface samples (e.g., Miles, 1985; Hayashi \& Rosenberry, 2002; Sophocleous, 2002; Fleckenstein et al., 2010). We also incorporate analytical uncertainty into our model by bootstrapping the distributions of $\delta^{13} \mathrm{C}$ values from each sample type (river, lake DIC, and lake DOC). We sampled the distributions 1000 times with replacement to calculate $\mathrm{F}_{\text {org }}$. All calculations were performed in $\mathrm{R}$ ( $\mathrm{R}$ Core Team, 2018).

\section{Results}

Community composition, abundance, and diversity

\section{$q P C R$}

We quantified archaeal and bacterial 16S rRNA gene sequences, and cyanobacterial 16S rRNA gene sequences, and eukaryotic 18S rRNA gene sequences to qualitatively estimate the contribution of these organisms to water column and sediment biomass. In general, bacterial 16S rRNA gene sequences were more abundant than archaeal 16S rRNA genes and 18S rRNA genes in all samples (Fig. S1). Archaeal 16S rRNA sequences were typically more abundant than eukaryotic 18S rRNA genes and were more abundant in sediments compared to water column samples. In contrast, cyanobacterial 16S rRNA sequences were usually detected in higher abundance in the water column samples compared to the sediments. In most samples, cyanobacterial 16S rRNA gene sequences were more abundant than $18 \mathrm{~S}$ rRNA genes.

\section{$16 S$ and $18 S$ rRNA amplicon sequencing}

We examined community composition in planktonic and sediment samples using $16 \mathrm{~S}$ and $18 \mathrm{~S}$ rRNA amplicon sequencing. Sequencing of 16S rRNA genes resulted in 773,701 sequences after quality control and removing chimeras. Clustering sequences at $97 \%$ identity resulted in 9,421 OTUs affiliated with bacteria and 1,016 OTUs affiliated with archaea. Sequencing of $18 \mathrm{~S}$ rRNA genes resulted in 1,754,164 sequences after quality control and removing chimeras. Clustering sequences at $98 \%$ identity resulted in 16,293 OTUs. In non-metric multidimensional scaling analyses, sediment samples clustered distinctly from water column samples for both $16 \mathrm{~S}$ and 18S rRNA analyses and not by the presence or absence of invasive mussels (Fig. S2).

At the phylum level, OTUs affiliated with cyanobacteria were abundant in the majority of the samples and archaea were much less abundant than those affiliated with bacteria (Fig. 1). In the Maumee River, and Kiser and Brookville Lake sediments, the sequences affiliated with and Beta- and Gammaproteobacteria were abundant (Fig. 1). OTUs affiliated with Actinobacteria and Alphaproteobacteria were abundant in the Ohio River and Licking River samples. In Buckeye Lake and Sandusky Bay, OTUs most closely related to Spartobacteria were abundant in addition to those affiliated with cyanobacteria. Small numbers of OTUs affiliated with Acidomicrobia, Chlorobi, Phycisphaerae, Planctomycetacia, and Saprospirae were recovered from most of the sites (Fig. 1). The most abundant archaeal OTUs were affiliated with the ammonia oxidizing archaea Nitrososphaerales, Woesearchaeia, and methanogens 
including Methanobacteriales, Methanomassiliicoccales, Methanomicrobiales, and Methanosarcinales were also consistently observed (Fig. S3).

A number of OTUs affiliated with algae and diatoms were recovered from both the water column and sediment samples (Fig. S4). Sequences affiliated with Diatomea were particularly abundant in the Ohio and Licking River samples, the upper Maumee River samples, and Lake Erie. Sequences affiliated with Chlorophyceae were observed in all river samples, Lake Erie, Brookville Lake, Buckeye Lake, and sediments from Kiser Lake. Sequences affiliated with ciliates (Intramacronucleata) and dinoflagellates (Dinophyceae) were also recovered from the majority of the samples. Algae, including Chlorophyceae, can represent significant fractions of phytoplankton biomass during cyanobacterial blooms.

\section{Cyanobacteria}

16S rRNA gene sequences affiliated with the genus Planktothrix were abundant in most of the samples with several notable exceptions (Fig. 2): In Brookville Lake, OTUs affiliated with Cylindrospermopsis and Planktothrix were abundant throughout the water column. OTUs affiliated with Microcystis spp. were recovered from the Ohio and Licking River along with smaller numbers of sequences of Pseudanabaena. Water column and sediment samples from Kiser Lake were composed of cyanobacterial OTUs affiliated with Microcystis, Planktothrix, and Cyanobium. In samples from the Auglaize, lower Maumee, and Sandusky Rivers, the majority of cyanobacterial OTUs were most closely related to Cyanobium spp.

\section{Diversity}

In general, sediment communities were more diverse than planktonic communities based on alpha diversity metrics for 16S rRNA (Fig. S5A) and 18S rRNA (Fig. S6A) but none of the differences were significant. There were also no significant differences in alpha diversity metrics in samples from sites that were impacted by invasive mussels compared to those without mussels (Fig. S5B; Fig. S6B). In principle coordinate analyses of the microbial (total 16S rRNA) composition and cyanobacterial community composition, distinct patterns were observed between the two (Fig. 3). When considering the total community composition, most sediment samples generally grouped together as did the Brookeville Reservoir samples and most of the river samples. In contrast, cyanobacterial sequences in the Brookeville Reservoir samples formed a distinct group from the rest of the samples. In both analyses, Lake Erie, Buckeye Lake, and Grand Lake Saint Marys samples generally clustered. This could be due to sample collection from shallow, well-mixed water columns (e.g., Sandusky Bay in Lake Erie).

\section{Geochemistry}

\section{Lakes and reservoirs}

Geochemical data indicate that lakes and reservoirs we sampled are well-mixed and impacted by abundance and activity of phototrophs in the water column (Table 1; Fig. 4). Secchi disk measurements from the water column of Grand Lake St. Marys, Buckeye Lake, Sandusky Bay, East Harbor State Park, and Bay View Boat Launch in Lake Erie, and Brookville Reservoir are consistent with increased turbidity due at least in part to cyanobacterial blooms in the water column (Table 1). In the water column of Grand Lake St. Marys, Buckeye Lake, Sandusky Bay in Lake Erie, and Brookville Reservoir, temperatures ranged from 25 to $29^{\circ} \mathrm{C}$ and temperature was relatively constant throughout the water column (Fig. 4). Grand Lake St. Marys, Buckeye Lake, Sandusky Bay, and Brookville Reservoir are relatively shallow, resulting in a wellmixed water column due to wind. Consistent with an active photoautotrophic population, the $\mathrm{pH}$ was above 8 in Grand Lake St. Marys, Buckeye Lake, the three sites in Lake Erie, and Brookville Reservoir (Fig. 4). At Grand Lake St. Marys, Buckeye Lake, the three sites in Lake Erie, and Brookville Reservoir, oxygen was above air saturation at the surface (Fig. 4). Nitrate concentration ranged from 40 to $81 \mu \mathrm{M}$ in Grand Lake St. Marys, Brookville Reservoir, and East Harbor State Park on Lake Erie (Table 1). At all other sites, nitrate was below detection limits. $\mathrm{NH}_{4}(\mathrm{~T})$ was only above detection limits in the pore water samples (Table 1). $\mathrm{P}$ (measured as total dissolved $\mathrm{P}$ detected in the $0.22 \mu \mathrm{m}$ filtered portion of the water) was below detection limits (detection limit $=0.52 \mu \mathrm{mol} / \mathrm{l}$ ) in the majority of the sites but was detected $(0.6$ to $3.8 \mu \mathrm{M})$ in samples from the Bay View Boat Launch on Lake 


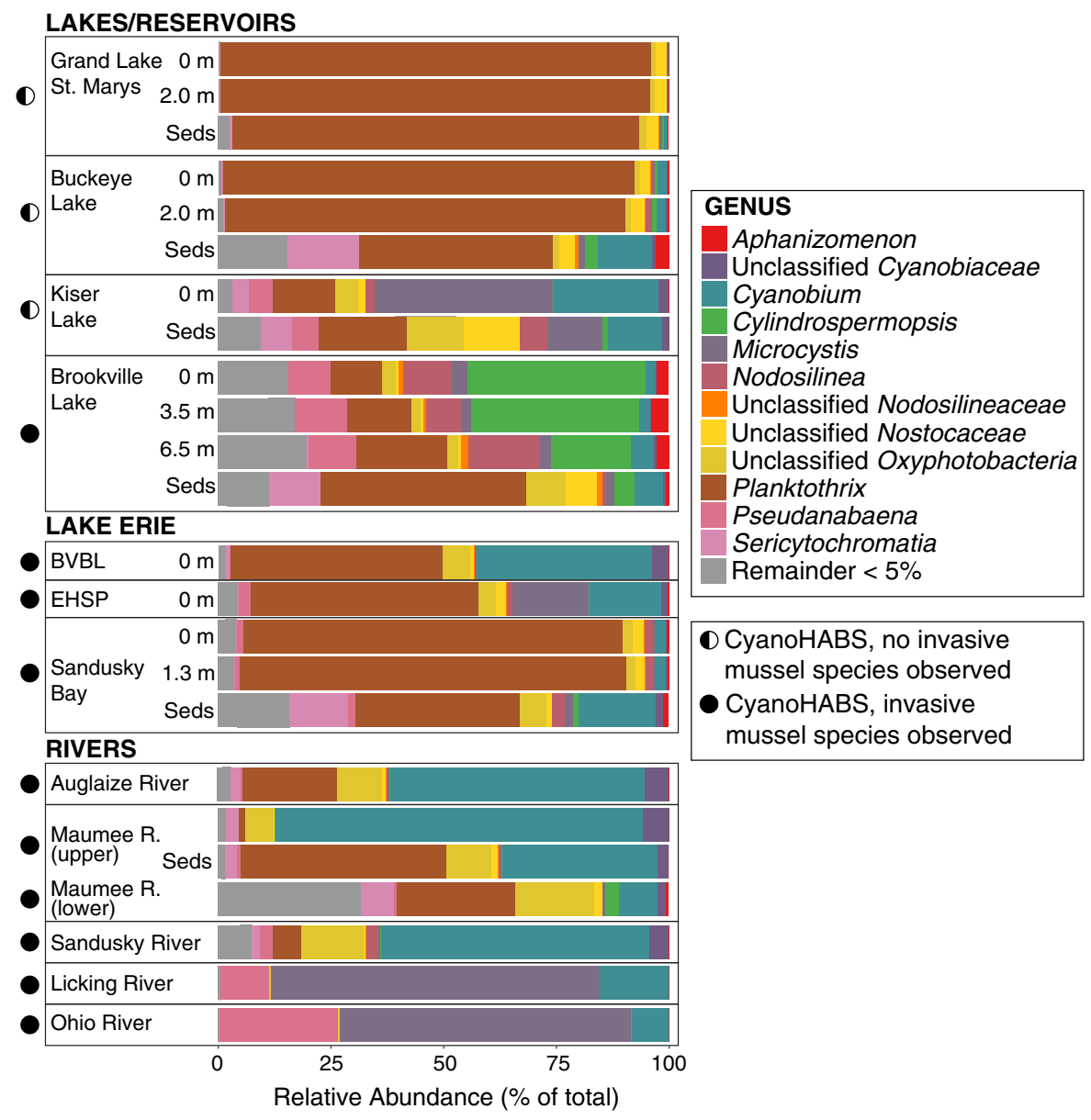

Fig. 2 Composition of cyanobacterial 16S rRNA gene sequences recovered from sediment and planktonic biomass in reservoirs, rivers, and lakes in Indiana, Ohio, and Kentucky. Representative OTUs for each library were binned at the Genus

Erie, Buckeye Lake, and Grand Lake St. Marys (at $2.0 \mathrm{~m}$ ) (Table 1).

\section{Rivers}

The geochemical attributes of the river samples were similar to water column samples. The temperature ranged from 25.4 to $28.6^{\circ} \mathrm{C}$ and the $\mathrm{pH}$ from 8.30 to 8.99 (Table 1). Dissolved oxygen was well above air saturation in the Maumee River (190.1\% and 254.3\%) and was also above air saturation in the Auglaize River (131.1\%), the Sandusky River (103.1\%), and the Licking River (103.1\%). Dissolved oxygen in the Ohio River was $99.8 \%$. No $\mathrm{NH}_{4}(\mathrm{~T})$ or phosphorus was detected in any of the river samples. Nitrate concentrations ranged from 47.2 $\mu \mathrm{M}$ in the Sandusky River, level (total number of OTUs = 198). Sample collection depths are indicated (surface where not indicated). Seds sediments collected at the water-sediment interface

$87.5 \mu \mathrm{M}$ in the Auglaize River, and $240.3 \mu \mathrm{M}$ in the Maumee River (Table 1). No nitrate was detected in the Maumee River sample site downstream of Defiance. In both water column and river samples, measurements of total or particulate $\mathrm{N}$ and $\mathrm{P}$ would likely have reflected substantial nutrient concentrations associated with the eutrophic status of the ecosystems. Indeed, long-term monitoring of the Maumee River suggests that while concentrations vary seasonally, soluble reactive phosphorus, total phosphorus, and total nitrogen are present throughout the year (Choquette et al., 2019). 

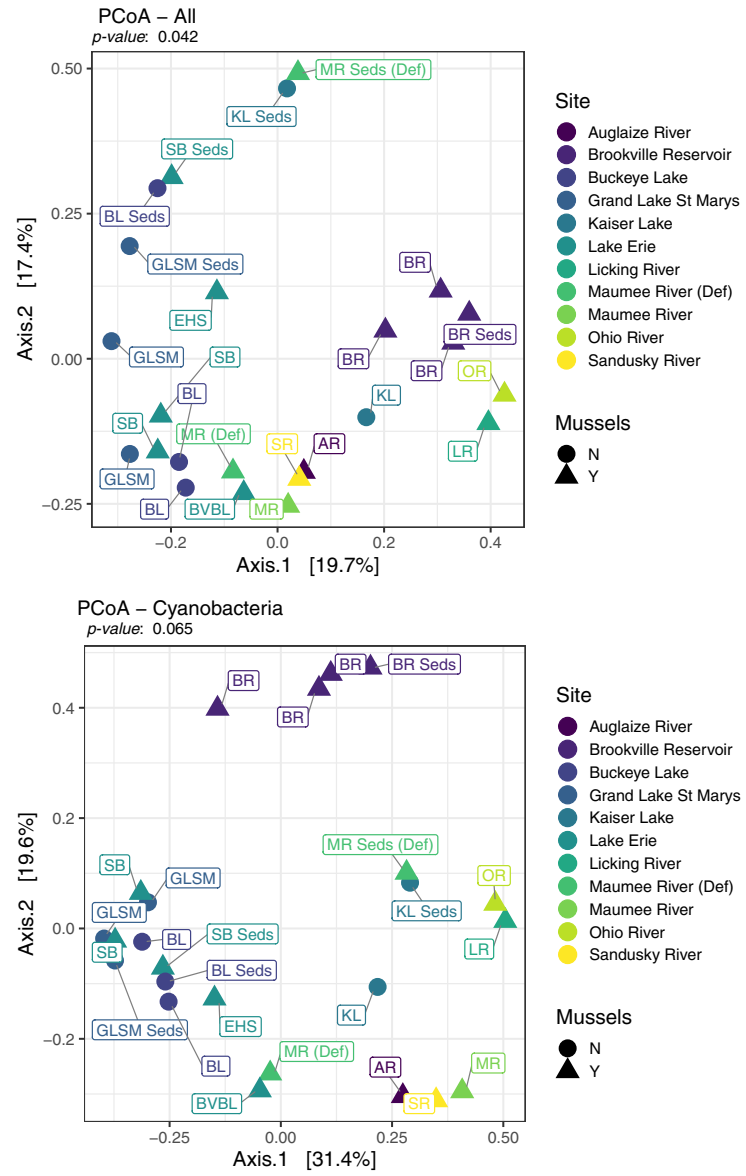

Fig. 3 Principal coordinate analysis for the total microbial community (16S rRNA, PCoA-All) and for the cyanobacterial fraction only (PCoA-Cyanobacteria). Cyano copies: abundance of the cyanobacterial 16S rRNA genes determined by qPCR; Seds: sediment samples. Geochemical results are reported in Table 1. Abbreviations: $A R$ Auglaize River, $B R$ Brookville Reservoir, $B L$ Buckeye Lake, $B V B L$ Bay View Boat Launch, EHSP East Harbor State Park, GLSM Grand Lake St. Marys, $K L$ Kaiser Lake, $L R$ Licking River, $M R$ Maumee River, $O R$ Ohio River, $S B$ Sandusky Bay

Carbon concentration and stable isotope analyses

\section{Dissolved inorganic carbon}

Lakes, reservoirs, and rivers display a range of dissolved inorganic carbon (DIC) concentrations and DIC $\delta^{13} \mathrm{C}$ values and DIC concentrations are typically higher in sediment porewater. DIC concentrations for the lakes and reservoirs ranged from lows of $1.1 \mathrm{mM}$ for the surface samples from Buckeye Lake and Sandusky Bay to the highest value of $3.3 \mathrm{mM}$ at $6.5 \mathrm{~m}$ in Brookville Reservoir (Table 1). Porewater DIC concentrations were all higher than the overlying water column, with the lowest value of $3.2 \mathrm{mM}$ in Buckeye Lake sediments and the highest of $4.1 \mathrm{mM}$ in Sandusky Bay sediments. River DIC concentrations fell between $1.7 \mathrm{mM}$ for the Licking and Ohio Rivers and $3.3 \mathrm{mM}$ for the Auglaize River sample. Lake and reservoir DIC $\delta^{13} \mathrm{C}$ values ranged from the lowest value of $-10.81 \%$ at Bay View Boat Launch to the highest value of $2.84 \%$ at the surface of Buckeye Lake (Table 1, Fig. 5). In all samples, porewater DIC $\delta^{13} \mathrm{C}$ values were more negative than the overlying water column and ranged from the lowest value of $-15.14 \%$ at Sandusky Bay to the highest value of $-2.42 \%$ at Grand Lake St. Marys (Table 1, Fig. 5). River DIC $\delta^{13} \mathrm{C}$ values fell between a low of $-9.96 \%$ for the Auglaize River to a high of $-6.61 \%$ for the Sandusky River, giving an average $\delta^{13} \mathrm{C}$ value of - 8.89\% (Table 1).

\section{Dissolved organic carbon}

Similar to DIC, lakes, reservoirs, and rivers display a range of dissolved organic carbon (DOC) concentrations and DOC $\delta^{13} \mathrm{C}$ values. In addition, DOC concentrations are typically higher in sediment porewater than in the water column. DOC concentration in the lakes and reservoirs fell between a low of $0.33 \mathrm{mM}$ at the $6.5 \mathrm{~m}$ depth of Brookville Lake to the highest value of $3.56 \mathrm{mM}$ at the surface of Buckeye Lake (Table 1). Porewater DOC concentrations ranged from a low of $0.09 \mathrm{mM}$ in Buckeye Lake sediments to a high of $0.66 \mathrm{mM}$ in Grand Lake St. Marys sediments. Riverine DOC concentrations fell between a low of $0.25 \mathrm{mM}$ in the Ohio River and a high of $1.03 \mathrm{mM}$ in the upper Maumee River. DOC $\delta^{13} \mathrm{C}$ values in lakes and reservoirs ranged between a low of $-27.80 \%$ at the $0 \mathrm{~m}$ depth of Kiser Lake and a high of $-15.37 \%$ at the surface of Buckeye Lake (Table 1, Fig. 5). Porewater DOC $\delta^{13} \mathrm{C}$ values ranged from -26.48 to $-29.44 \%$ in Grand Lake St. Marys and Buckeye Lake sediments. The sample from Sandusky Bay was lost (bottle broken in transit), and Brookville Lake bottom sediments were loose sand, gravel, and broken shells, negating porewater sampling. River DOC $\delta^{13} \mathrm{C}$ values ranged from $-20.19 \%$ for the upper Maumee River to $-27.53 \%$ for the Ohio River (Table 1). 
Table 1 Geochemical and physical analytical results for water column and sediment samples

\begin{tabular}{|c|c|c|c|c|c|c|c|c|c|c|c|c|c|c|c|c|c|c|c|c|c|c|}
\hline & & \multirow[b]{2}{*}{$\mathrm{pH}$} & \multirow[b]{2}{*}{$\begin{array}{l}\text { Temp. } \\
\left({ }^{\circ} \mathrm{C}\right)\end{array}$} & \multirow{2}{*}{\multicolumn{2}{|c|}{$\begin{array}{c}\text { Cond. } \\
\mu \mathrm{S} / \mathrm{c}\end{array} \begin{array}{c}\text { D.O. } \\
\mathrm{m}\end{array}$}} & \multirow[b]{2}{*}{$\begin{array}{c}\mathrm{NH}_{4}(\mathrm{~T}) \\
\mu \mathrm{M}\end{array}$} & \multirow[b]{2}{*}{$\begin{array}{c}\mathrm{NO}_{3}^{-} \\
\mu \mathrm{M}\end{array}$} & \multicolumn{4}{|c|}{ Biomass } & \multirow[b]{2}{*}{$\begin{array}{l}\text { DIC } \\
\mathrm{mM}\end{array}$} & \multirow[b]{2}{*}{$\begin{array}{c}\delta^{13} \mathrm{C} \\
\% 0\end{array}$} & \multirow[b]{2}{*}{$\begin{array}{c}\mathrm{C}_{\mathrm{CaCO}} \\
3 \\
\% \\
\%\end{array}$} & \multirow[b]{2}{*}{$\begin{array}{c}\delta^{13} \mathrm{C} \\
\% 0\end{array}$} & \multirow[b]{2}{*}{$\begin{array}{l}\mathrm{Cl}^{-} \\
\mathrm{mM}\end{array}$} & \multirow[b]{2}{*}{$\begin{array}{c}\mathrm{SO}_{4}{ }^{2-} \\
\mathrm{mM}\end{array}$} & \multirow[b]{2}{*}{$\begin{array}{c}\text { Total } \\
\text { dissolved P } \\
\mu \mathrm{M}\end{array}$} & \multirow[b]{2}{*}{$\begin{array}{r}\mathrm{Na} \\
\mathrm{mM}\end{array}$} & & \\
\hline & $\begin{array}{l}\text { GPS } \\
\text { Easting }\end{array}$ & Northing & & & & & & & $\begin{array}{c}\text { Total } \\
\mathrm{N} \\
\% \mathrm{~N}\end{array}$ & $\begin{array}{c}\delta^{15} \mathrm{~N} \\
\%\end{array}$ & $\begin{array}{l}\mathrm{C}_{\text {org }} \\
\% \mathrm{C}\end{array}$ & $\begin{array}{c}\delta^{13} \mathrm{C} \\
\% 0\end{array}$ & & & & & & & & & $\begin{array}{l}\mathrm{Mn} \\
\mathrm{nM}\end{array}$ & $\begin{array}{r}\mathrm{Fe} \\
\mathrm{nM}\end{array}$ \\
\hline Grand Lake & 708649 (16S) & 4487570 & & & & & & & & & & & & & & & & & & & & \\
\hline $0 \mathrm{~m}$ & & & 9.50 & 25.9 & 378.5 & 134.2 & bdl & 64.1 & & 13.18 & & -23.99 & 1.6 & 2.45 & & & 0.79 & 0.14 & bdl & 0.770 .70 & 25 & 188 \\
\hline $2.0 \mathrm{~m}$ & & & 9.20 & 25.2 & 378.7 & 82.9 & bdl & 40.9 & & 12.26 & & nd & 1.8 & 1.12 & & & 0.79 & 0.33 & 0.90 & $0.77 \quad 0.70$ & 31 & 210 \\
\hline Porewater & & & nd & nd & nd & nd & 357 & nd & nd & & & & 4.0 & -2.42 & & & 0.83 & 0.43 & bdl & nd nd & nd & nd \\
\hline Sediments & & & & & & & & & 0.67 & 8.18 & 4.14 & -24.57 & & & 18.1 & -4.69 & & & & & & \\
\hline Buckeye Lake & $369509(17 \mathrm{~S})$ & 4418855 & & & & & & & & & & & & & & & & & & & & \\
\hline $0 \mathrm{~m}$ & & & 9.70 & 28.7 & 311.2 & 169.0 & bdl & bdl & & 8.99 & & -21.95 & 1.1 & 2.84 & & & 0.92 & 0.16 & 1.19 & 0.660 .59 & 87 & 449 \\
\hline $0.4 \mathrm{~m}$ & & & 8.50 & 28.5 & 349.5 & 7.1 & bdl & bdl & bdl & & & -21.63 & 1.2 & 2.09 & & & 0.89 & 0.16 & 1.13 & $\begin{array}{lll}0.65 & 0.59\end{array}$ & 116 & 902 \\
\hline Porewater & & & $\mathrm{nd}$ & & nd & nd & 257 & nd & nd & & & & 3.2 & -7.80 & & & 0.96 & 0.10 & 3.82 & 0.570 .81 & 15883 & 4609 \\
\hline Sediments & & & & & & & & & 0.61 & 6.21 & 4.17 & -25.32 & & & 16.6 & -0.75 & & & & & & \\
\hline Kaiser Lake & 248821 (16S) & 4452314 & & & & & & & & & & & & & & & & & & & & \\
\hline $0 \mathrm{~m}$ & & & 9.22 & 29.2 & 323.9 & 183.7 & bdl & 48.9 & 2.48 & bdl & nd & -31.54 & 2.3 & -5.75 & & & 0.4 & 0.14 & bdl & $0.4 \quad 0.6$ & 46 & 1005 \\
\hline Brookeville Reservoir & 672947 (16S) & 4374461 & & & & & & & & & & & & & & & & & & & & \\
\hline $0 \mathrm{~m}$ & & & 8.70 & 27.7 & 411.6 & 109.3 & bdl & 76 & bdl & & & -30.69 & 2.6 & -5.72 & & & 0.65 & 0.22 & bdl & $0.5 \quad 0.01$ & bdl & bdl \\
\hline $3.5 \mathrm{~m}$ & & & 8.00 & 25.9 & 413.4 & 38.1 & bdl & 79.7 & bdl & & & -30.45 & 2.7 & -7.68 & & & 0.64 & 0.22 & bdl & $0.5 \quad 0.01$ & bdl & bdl \\
\hline $6.5 \mathrm{~m}$ & & & 7.80 & 25.2 & 428.1 & 8.9 & bdl & 77.2 & bdl & & & -31.17 & 3.3 & -9.94 & & & 0.64 & 0.21 & bdl & $0.5 \quad 0.01$ & 24 & bdl \\
\hline Sediments & & & & & & & & & 0.06 & bdl & & -27.66 & & & 36.2 & -1.26 & & & & & & \\
\hline Lake Erie & & & & & & & & & & & & & & & & & & & & & & \\
\hline Sandusky Bay & $347261(17 \mathrm{~S})$ & 4594335 & & & & & & & & & & & & & & & & & & & & \\
\hline $0 \mathrm{~m}$ & & & 9.40 & 25.1 & 303.8 & 114.5 & bdl & bdl & bdl & & & -25.60 & 1.1 & -4.97 & & & 0.46 & 0.48 & bdl & 0.360 .78 & 44 & 432 \\
\hline $1.3 \mathrm{~m}$ & & & 8.40 & 24.8 & 303.5 & 36.8 & bdl & bdl & bdl & & & -26.94 & 1.2 & -5.72 & & & 0.46 & 0.47 & bdl & 0.370 .78 & 49 & 338 \\
\hline Porewater & & & nd & nd & nd & nd & 114 & nd & bdl & & & & 4.1 & -15.14 & & & 0.76 & 0.72 & bdl & 0.050 .16 & 1582 & 1071 \\
\hline Sediments & & & & & & & & & 0.53 & 8.02 & 3.21 & -26.89 & & & 16.9 & -3.37 & & & & & & \\
\hline East Harbor S.P. & $350059(17 \mathrm{~S})$ & 4601461 & & & & & & & & & & & & & & & & & & & & \\
\hline $0 \mathrm{~m}$ & & & 9.23 & 26.4 & 279.9 & 136.5 & bdl & 81.4 & bdl & & & -24.52 & 1.5 & -3.16 & & & 0.45 & 0.23 & bdl & 0.380 .76 & bdl & 98 \\
\hline Bay View B.L. & 294081 (17S) & 4619918 & & & & & & & & & & & & & & & & & & & & \\
\hline $0 \mathrm{~m}$ & & & 9.19 & 26.3 & 403.0 & 181.8 & bdl & bdl & bdl & & & -28.43 & 2.4 & -10.81 & & & 0.73 & 0.29 & 0.99 & 0.761 .12 & 53 & 528 \\
\hline River Samples & & & & & & & & & & & & & & & & & & & & & & \\
\hline Auglaize River & $716515(16 \mathrm{~S})$ & 4567748 & 8.41 & 27.5 & 546.0 & 131.1 & bdl & 87.5 & bdl & & & \begin{tabular}{l|l|}
-28.02 \\
\end{tabular} & 3.3 & -9.96 & & & 0.83 & 0.53 & bdl & 0.741 .50 & 58 & 109 \\
\hline Maumee River & 708129 (16S) & 4572339 & 8.99 & 26.8 & 514.0 & 254.3 & bdl & bdl & bdl & & & -25.50 & 2.8 & -8.15 & & & 0.90 & 0.47 & bdl & 0.841 .36 & 80 & 310 \\
\hline & $276184(16 \mathrm{~S})$ & 4602857 & 8.98 & 28.3 & 620.0 & 190.1 & bdl & 240.3 & bdl & & & -31.13 & 2.5 & -9.39 & & & 1.89 & 0.50 & bdl & 1.591 .35 & 78 & 172 \\
\hline Sandusky River & $323446(17 \mathrm{~S})$ & 4578823 & 8.81 & 28.6 & 519.0 & 103.1 & bdl & 47.2 & bdl & & & -28.51 & 2.3 & -6.61 & & & 1.04 & 0.82 & bdl & 0.891 .16 & 106 & 278 \\
\hline Licking River & $715889(16 \mathrm{~S})$ & 4329558 & 8.40 & 25.4 & 449.0 & 103.1 & bdl & 76.2 & & 16.90 & & -29.16 & 1.7 & -9.65 & & & 0.89 & 0.78 & bdl & 1.160 .92 & 317 & bdl \\
\hline Ohio River & $715889(16 \mathrm{~S})$ & 4329559 & 8.30 & 25.5 & 460.0 & 99.8 & bdl & 60.2 & & 18.12 & & -28.90 & 1.7 & -9.56 & & & 0.93 & 0.83 & bdl & 1.080 .92 & 586 & bdl \\
\hline
\end{tabular}

Total dissolved $\mathrm{P}$ measured as $\mathrm{P}$ detected in the $0.22 \mu \mathrm{m}$ filtered portion of the water

Detection limits: NH4 (T) $-0.7 \mu \mathrm{M}$, total dissolved $\mathrm{P}-0.52 \mu \mathrm{M}, \mathrm{Mn}-20 \mathrm{nM}, \mathrm{Fe}-20 \mathrm{nM})$

$n d$ not determined, $b d l$ below detection limits, Temp. temperature, Cond. conductivity, D.O. dissolved oxygen, \% Sat. percent saturation, $\mathrm{C}_{\mathrm{org}}$ total organic carbon, $\mathrm{DIC}$ dissolved inorganic carbon, $\mathrm{C}_{\mathrm{CaCO}_{3}}$ total carbonate

\section{Particulate organic carbon (seston)}

Particulate organic carbon (POC), or seston $(>0.3 \mu \mathrm{m}$ filter size), ranged two orders of magnitude across sites. Grand Lake St. Marys had the highest concentration ( $1719 \mu \mathrm{mol} \mathrm{C/1}$ at $2 \mathrm{~m}$ depth), followed by Buckeye Lake $(1203 \mu \mathrm{mol} \mathrm{C} / \mathrm{l}$ at $0.4 \mathrm{~m}$ depth) (Table 1, Fig. 5). The lowest POC concentrations were found at Sandusky Bay $(46.6 \mu \mathrm{mol} \mathrm{C} / 1$ at the surface), with Brookville Lake, Kiser Lake, and the other Lake Erie sites falling between (Table 1, Fig. 5). POC concentrations in the rivers ranged from a high of $507 \mu \mathrm{mol} \mathrm{C} / \mathrm{l}$ in the upper Maumee River to a low of $32 \mu \mathrm{mol} \mathrm{C} / 1$ in the Auglaize River (Table 1). POC $\delta^{13} \mathrm{C}$ values were the lowest at Kiser Lake (- 31.54\%o at the surface) and the highest at Buckeye Lake (-21.63\%o at the $0.4 \mathrm{~m}$ depth). River POC $\delta^{13} \mathrm{C}$ values fell between a low of $-31.13 \%$ for the lower Maumee River and a high of $-25.50 \%$ for the upper Maumee River.

\section{Sediment organic and inorganic carbon}

Surface (top $\sim 2 \mathrm{~cm}$ ) sediment samples were collected at Grand Lake St. Marys, Buckeye Lake, Brookville Lake, and Sandusky Bay. Brookville Lake sediments contained the lowest organic carbon content $(0.62 \%)$ while the other sediments ranged from 3.21 to $4.17 \%$ organic carbon (Table 1). Sediment organic carbon $\delta^{13} \mathrm{C}$ values range between a low of $-27.66 \%$ in Brookville Lake sediments and - 24.57\%o at Grand Lake St. Marys (Table 1, Fig. 5). Brookville Lake 
Fig. 4 Physical and geochemical parameters for the five lakes/reservoirs plotted versus depth in the water column. Temp. temperature, Cond. Conductivity, D.O. optical dissolved oxygen, $O R P$ oxidation reduction potential. Note that the $\mathrm{X}$-axis scales are different for temperature, conductivity, and turbidity. The light gray line in the D.O. plots represent values toxic for fish $(<4 \mathrm{mg} / \mathrm{l})$, the dark gray line values toxic for invertebrates $(<1 \mathrm{mg} / \mathrm{l})$. Spikes in turbidity and associated drops in ORP at the bottom of depth profiles (i.e., Grand Lake St. Marys, Brookville Lake, Sandusky Bay) may indicate interaction with anoxic sediments
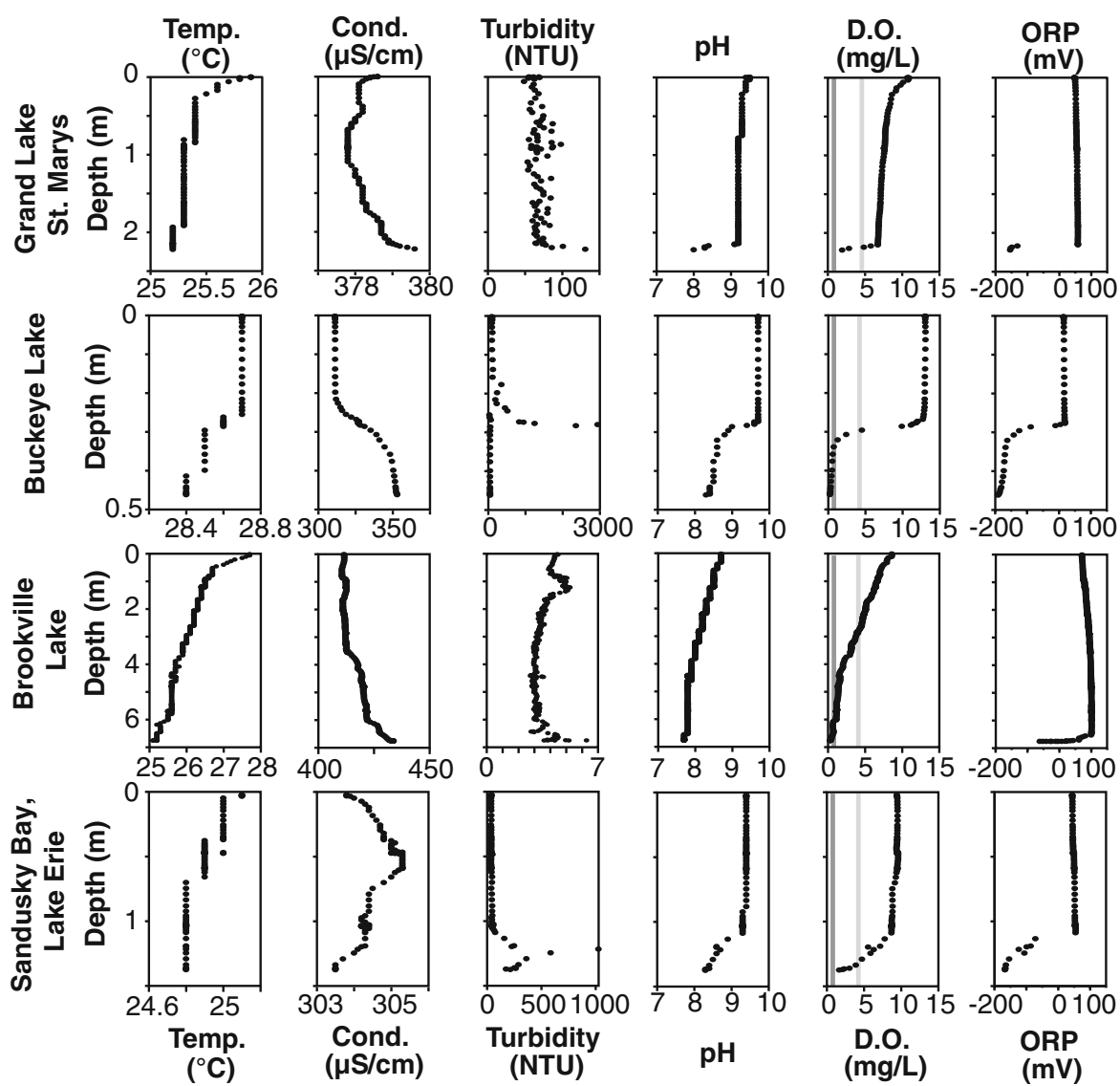

sediments (with visible mussel shell fragments) had the highest carbonate concentration $(36.2 \%)$, while Buckeye Lake sediments had the lowest (16.6\%) (Table 1, Fig. 5). Sediment carbonate $\delta^{13} \mathrm{C}$ values ranged from $-4.69 \%$ (Grand Lake St. Marys sediments) to $2.09 \%$ o (Buckeye Lake sediments).

\section{Biomass and sediment associated nitrogen}

Organic nitrogen tracked with organic carbon concentration in the lakes, reservoirs, and rivers. Seston organic nitrogen concentrations in lakes and reservoirs fell between a high of $226.2 \mu \mathrm{mol} \mathrm{N} / 1$ at the $2 \mathrm{~m}$ depth of Grand Lake St. Marys and a low of $6.93 \mu \mathrm{mol} \mathrm{N} / 1$ at the surface of Sandusky Bay (Table 1). Seston organic nitrogen concentrations in rivers fell between $55.29 \mu \mathrm{mol} \mathrm{N} / 1$ at the upper Maumee River and $5.10 \mu \mathrm{mol} \mathrm{N} / \mathrm{l}$ at the Auglaize River (Table 1). Sediment organic nitrogen concentrations fell between $2.48 \%$ at Kiser Lake and
$0.06 \%$ at Brookville Lake. Lake, reservoir, and river seston organic nitrogen $\delta^{15} \mathrm{~N}$ values were all positive, ranging from $7.77 \%$ in the Upper Maumee River to $18.12 \%$ in the Ohio River. Lake and reservoir sediment $\delta^{15} \mathrm{~N}$ values were also positive, falling between $6.21 \%$ at Buckeye Lake and $8.18 \%$ at Grand Lake St. Marys (Table 1).

\section{Discussion}

We present community composition and abundance data of planktonic and sediment microbes across a range of eutrophic lakes and reservoirs on select aquatic ecosystems with known mussel presence or absence that have been impacted by cyanobacterial blooms in Ohio, Indiana, and Kentucky, including portions of Lake Erie. While Lake Erie is wellstudied with respect to eutrophication, few studies have examined cyanoHABs and environmental 


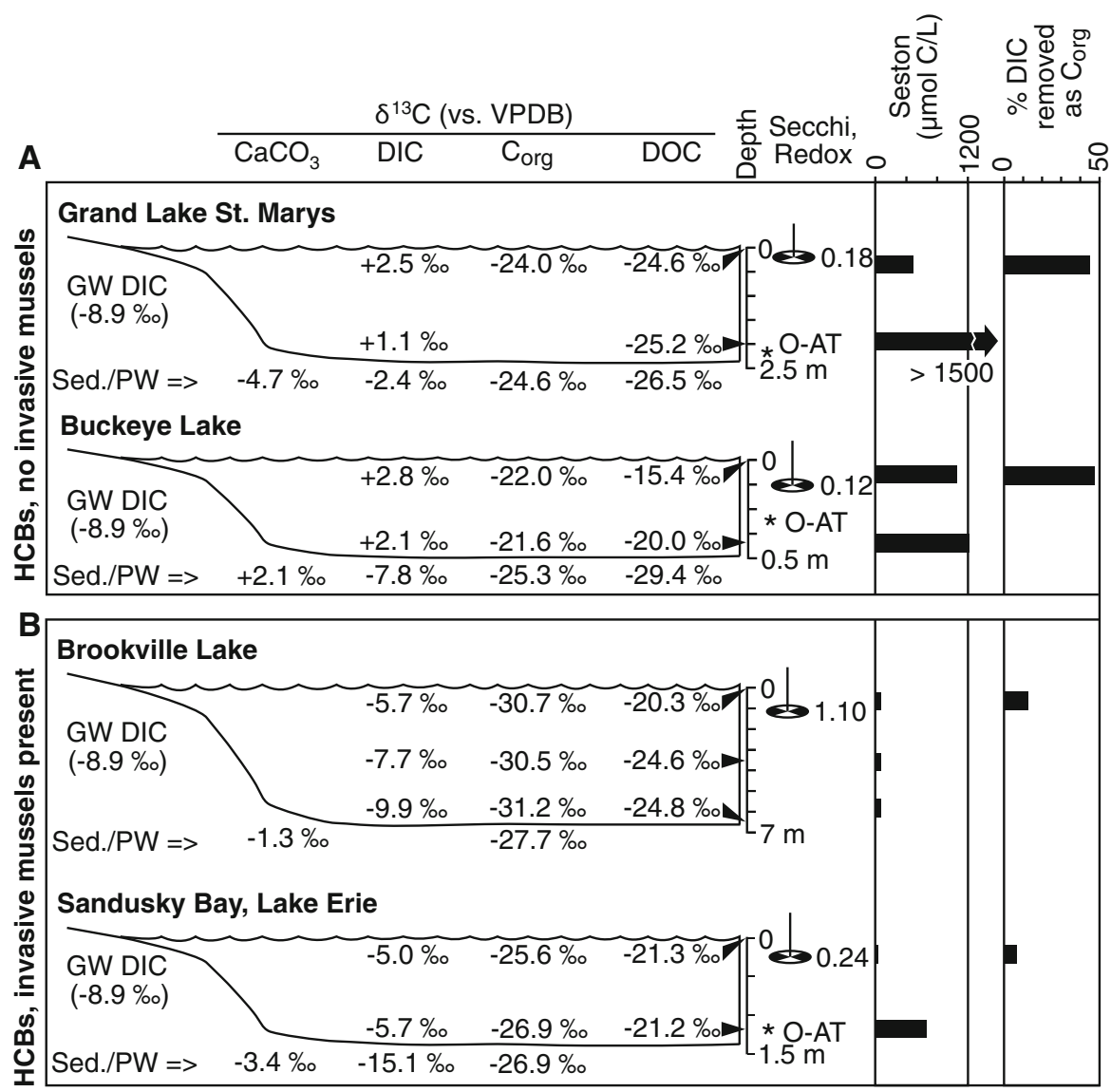

Fig. 5 Carbon isotope values (A) and percent carbon removed in lakes and reservoirs (B). A Carbon isotope values for water column and sediment samples, Secchi disk depths, and percent DIC removed as organic carbon for the five lakes/reservoirs in western Ohio and eastern Indiana, USA are shown. $H C B s$ harmful blooms of cyanobacteria, DIC dissolved inorganic carbon, $C_{\text {org }}$ organic carbon, $D O C$ dissolved organic carbon, $G W$ groundwater, $O-A T$ oxic-anoxic transition (asterisk denotes depth location of the transition), Sed./PW sediment/porewater.

stressors, including invasive mussel species, in other impacted lakes and reservoirs in the region. We combine amplicon data with stable carbon and nitrogen isotopes to examine biogeochemical cycling in these ecosystems. With these data, we develop a framework that, with higher resolution sampling and inclusion of ecosystem variability, can be used to assess the effects of invasive mussels on biogeochemical cycling, most imperatively carbon cycling and burial, in eutrophic ecosystems impacted by cyanoHABs.
GW DIC $\delta^{13} \mathrm{C}$ values are the average of river DIC values. B Percent carbon removed in lakes and reservoirs. Bars represent analytical error. Gray line indicates average carbon removal in the global oceans. Abbreviations: $B L$ Buckeye Lake*, GLSM Grand Lake St. Marys*, EHSP East Harbor State Park, $S B$ Sandusky Bay, $B R$ Brookville Reservoir, $K L$ Kaiser Lake*, $B V B L$ Bay View Boat Launch, * lakes with cyanoHABs only

Community composition

\section{Cyanobacteria}

Consistent with increased phototroph productivity and biomass during cyanoHABs, sequences affiliated with cyanobacteria were abundant in our samples (both planktonic and sediment samples, Fig. 1). However, the abundance of cyanobacterial sequences generally decreased with depth and were the lowest in sediment samples likely reflecting lowered benthic light availability (Fig. 1; Fig. S1). 
Microcystis is well-studied in the context of toxic cyanobacteria blooms. Planktothrix spp. are also common constituents of harmful blooms-they are often low-light adapted, can tolerate a larger range of temperatures than other cyanobacteria (Halstvedt et al., 2007), and can produce cyanotoxins including microcystin and oscillapeptin J (Blom et al., 2003; Christiansen et al., 2003; Komárek and Komárková, 2004). In our study, sequences affiliated with the genus Microcystis were only abundant in the Ohio and Licking Rivers and Kiser Lake. In contrast, sequences affiliated with the genus Planktothrix were abundant in Grand Lake St. Marys, Buckeye Lake, Brookville Lake, Lake Erie, and the Maumee River (Fig. 2). Microscopy-based studies identified Microcystis as the dominant member of bloom biomass in Lake Erie (Bridgeman et al., 2013; Michalak et al., 2013; Steffen et al., 2014; Harke et al., 2016) while the toxin production and bloom formation in Sandusky Bay in Lake Erie have been attributed to Planktothrix spp. (Davis et al., 2015; Salk et al., 2018). Recent studies found that Microcystis spp. dominated Lake Erie cyanoHABs near the Maumee River while Planktothrix spp. were abundant near the Sandusky River (Rinta-Kanto \& Wilhelm, 2006; Conroy et al., 2014; Jankowiak et al., 2019). Here, we recovered abundant sequences affiliated with Planktothrix spp. from all our sites in Lake Erie including East Harbor State Park, Bay view Boat Launch, and Sandusky Bay. However, a more diverse community of cyanobacteria including sequences affiliated with Dolichospermum (formerly Anabaena), Microcystis, Pseudanabaena, Synechococcus, and unclassified genera have been observed in Lake Erie blooms (Ouellette et al., 2006; Gobler et al., 2008; Davis et al., 2012; Berry et al., 2017). In Grand Lake St. Marys, seasonal cyanoHABs have been attributed to Planktothrix (Steffen et al., 2014) which is consistent with our data (Fig. 2). Planktothrix and Cylindrospermopsis were both abundant in Brookville Late: the former was abundant in the sediments while sequences affiliated with Cylindrospermopsis, which can produces the hepatotoxin cylindrospermopsin, were abundant in the upper water column samples (0 and $3.5 \mathrm{~m}$ ) (Fig. 2). Cylindrospermopsis spp. have been observed in small shallow lakes throughout North America and Lake Erie. In studies of Sandusky Bay in Lake Erie, Cylindrospermopsis accounted for a relatively small fraction of the biomass (typically < 2\%) (Conroy et al., 2007). In this study, water temperature, shallow depth, and adequate nutrients were linked to the occurrence of Cylindrospermopsis. Temperature in the upper water column of Brookeville Lake was close to $28^{\circ} \mathrm{C}$ and nitrate levels were the highest we observed $(76-80 \mu \mathrm{M})$ which could help explain the abundance of Cylindrospermopsis at the time our samples were collected.

The dynamics of the composition of cyanobacteria throughout bloom formation are not captured by our single time point sampling and remain largely enigmatic across the span of eutrophic systems: cyanoHABs can display spatial and temporal dynamics and changes in water geochemistry can occur on short timescales (Woodhouse et al., 2015; Harke et al., 2016). For instance, Berry et al. (2017) note that the cyanobacterial community composition in Lake Erie blooms fluctuates over time but that Microcystis and Synechococcus sequences were the most abundant in the bloom. Other studies note Planktothrix spp. are abundant at the beginning and end of cyanobacterial blooms in eutrophic lakes (Lampert \& Sommer, 1997). In contrast to previous studies, the majority of cyanobacterial OTUs we recovered from the Auglaize, lower Maumee, and Sandusky Rivers were most closely related to Cyanobium spp. Previous studies found abundant Microcystis in the Maumee and Sandusky Rivers (Conroy et al., 2014) and Planktothrix in the Maumee River (Kutovaya et al., 2012; McKay et al., 2018). We also observed a small number of algae and diatoms in our water column samples. The abundance of these eukaryotes also likely depends on seasonality and the influx of nutrients and increase in temperature that lead to the formation of harmful blooms. For instance, in Lake Harsha (a eutrophic reservoir in southwestern Ohio), algae were more abundant prior to and following the bloom of cyanobacteria (Chen et al., 2017). Thus, our observations of abundant Microcystis in the Ohio and Licking Rivers, Cylindrospermopsis in Brookeville Lake, Cyanobium in the Auglaize, lower Maumee, and Sandusky Rivers, and Planktothrix in most lakes and reservoirs, could reflect sampling time (e.g., September and August, respectively).

\section{Potential biogeochemical cycling in blooms assemblages}

Our data highlight a diverse community of aerobic heterotrophic bacteria implicated in $\mathrm{C}, \mathrm{N}$, and $\mathrm{P}$ 
cycling and underscore the need for systematic studies of spatial and temporal dynamics in harmful blooms beyond the dominant primary producer component. Microbiota that were consistently observed in the "core microbiome" include members of the Proteobacteria, Acidobacteria, Acidomicrobia, Planctomycetacia, and Spartobacteria. OTUs affiliated with these lineages were most closely related to aerobic, heterotrophic taxa including Chthoniobacterales within the Spartobacteria (Figs. 1, 6). OTUs affiliated with Accumulibacter (within the subclass Betaproteobacteria) and Actinomycetales (Actinobacteria) including Tetrasphaera spp. were recovered from all lake samples (water column and sediments) (Figs. 1, 6). Microbes within these lineages are polyP-accumulating organisms and have been implicated in enhanced biological phosphorus removal (McMahon $\&$ Read, 2013). Planctomycetacia are often observed in close association with phototrophs in aquatic habitats, including in eutrophic Lake Taihu (Cai et al., 2013) and have been implicated in degradation of phototroph biomass (Pizzetti et al., 2011a, b). Heterotrophic bacteria in blooms assemblages have also been indicated in toxin degradation including members of the Caulobacterales (Alphaproteobacteria) and Xanthomonadales (Gammaproteobacteria), and Burkholderiales (subclass Betaproteobacteria) (Mou et al., 2013). Sequences affiliated with these lineages were recovered from the majority of our samples (Figs. 1, 6). OTUs affiliated with ammonia oxidizing archaea Nitrososphaerales were abundant in most samples including samples from the water column and sediments (Fig. S3). The functional gene for $\mathrm{NH}_{4}{ }^{+}$oxidation, amoA, was detected in sediments of hypereutrophic Lake Taihu, particularly archaeal amoA (Hampel et al., 2019b). Ammonia oxidation could compete with bloom-forming cyanobacteria for ammonia and/or consume ammonia from cyanoHAB biomass. Both scenarios would contribute to nitrogen depletion consistent with the low levels of ammonia measured in our sites. OTUs affiliated with the Woesearchaeia were also abundant, particularly in water column samples as well as the Licking and Ohio River samples. Smaller numbers of OTUs affiliated with methanogens including Methanobacteriales, Methanomassiliicoccales, Methanomicrobiales, and Methanosarcinales were also consistently observed (Fig. S3). Methanogenesis is an important process in lake sediments for the degradation of organic matter and biomass from cyanoHABs can serve as a labile carbon source for methanogens (Schwarz et al., 2008; Duc et al., 2010; West et al., 2012; Grasset et al., 2018).

\section{Environmental variables and community diversity}

We employed principal coordinate analysis and constrained coordination analyses to examine relationships between community diversity and environmental variables including the presence and absence of invasive mussel species. Unique clustering of planktonic $16 \mathrm{~S}$ and $18 \mathrm{~S}$ rRNA sequences suggests site factors other than mussel presence/absence are important to determining these microbial communities. In principle component analyses of the microbial (total 16S rRNA) composition and cyanobacterial community composition, a significant relationship was observed between community composition for the total community composition and the presence of mussels (Fig. 3A, $P$ value 0.042 ). When only considering the cyanobacteria, a significant relationship was not observed (Fig. 3B, $P$ 0.065). In constrained coordination analyses of community composition and environmental variables, we observed distinct patterns in community composition and environmental variables between the complete microbial

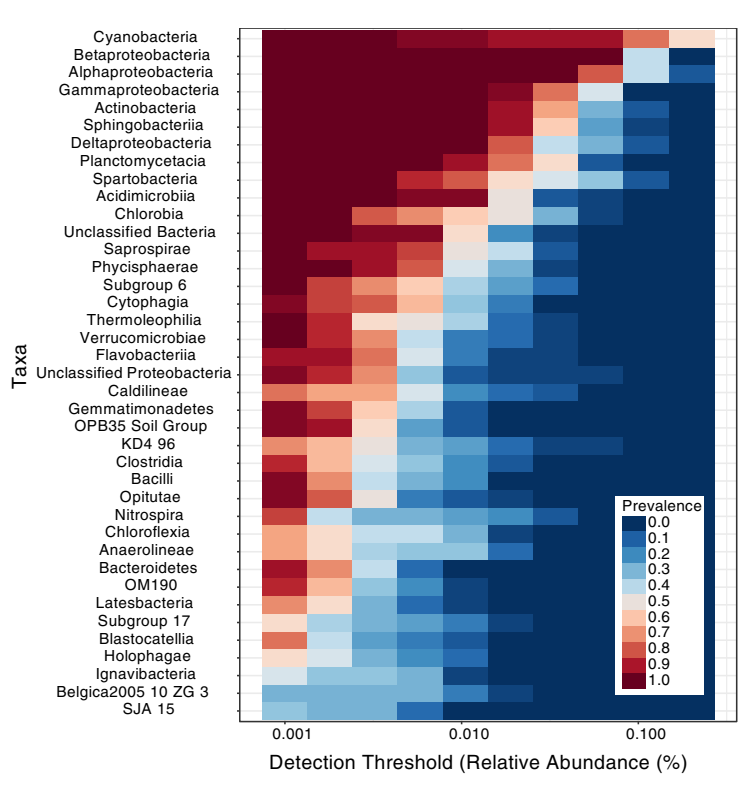

Fig. 6 Core microbiome of 16S rRNA sequences at the Class (A) and Order (B) level recovered from reservoirs, rivers, and lakes in Ohio, Kentucky, and Indiana 
community and the cyanobacterial fraction (Fig. 7). When considering the entire microbial (16S rRNA) community, dissolved oxygen, chloride, calcium, and DIC concentration were correlated with the majority of the water column samples from Lake Erie, Buckeye Lake, and Grand Lake Saint Marys as well as the Auglaize, Maumee, and Sandusky River samples. Sediment samples from Lake Erie, Buckeye Lake, and Grand Lake Saint Marys were associated with elevated $\mathrm{Mn}, \mathrm{Fe}$, ammonium, organic carbon, and phosphorus concentrations (Fig. 7). No environmental variables were associated with the Brookeville Reservoir samples or the Ohio and Licking River samples. When considering only the cyanobacterial fraction of the microbial community, variables including $\mathrm{Fe}, \mathrm{Mn}$, DIC, P, ammonium, and organic carbon were correlated with samples sediment and water column samples from Lake Erie, Buckeye Lake, and Grand Lake Saint Marys while as the Auglaize, Maumee, and Sandusky River samples where correlated with sulfate, temperature, $\mathrm{Na}$, conductivity, and ${ }^{13} \mathrm{C}$ DIC (Fig. 7). Nitrate was associated with Kaiser Lake samples and the Ohio and Licking River samples. These data suggest that environmental variables affect community composition in different ways.

In general, trends in species abundance, diversity, or evenness were stronger between sampling location or depth than between ecosystems with or without invasive mussels, suggesting invasive mussel species may not be greatly impacting microbial community compositions in these sites at the time of sampling. Unique clustering of planktonic $16 \mathrm{~S}$ and $18 \mathrm{~S}$ rRNA sequences suggests site factors other than mussel presence/absence are important to determining these microbial communities (Fig. 3). Similar to the community composition data, these observations are confounded by temporal and spatial variability in blooms and require higher resolution sampling (i.e., Berry et al., 2017) at more bloom-impacted sites. Thus, strategies to alleviate the toxicity and proliferation of cyanoHABs should carefully consider the bloom dynamics of the entire microbial community. While mussels may assist in proliferation of bloomforming cyanobacteria, this effect is not detected in the composition of cyanobacteria in our study which are peak bloom. Finally, identifying biotic interactions between cyanobacteria and water column heterotrophs and how these dictate bloom characteristics including proliferation, toxicity, and longevity warrants further study.

\section{Limitations of DNA-based analyses}

Previous studies have observed an increase in cyanobacterial biomass with nutrient input (Lürling et al., 2017). However, estimating the cyanobacterial portion of the biomass is difficult: algae and cyanobacteria (and some anoxygenic phototrophs) use chlorophyll $a$ and its abundance is not necessarily correlated with cell number. Direct cell counts or cell sorting are time consuming and the latter is expensive. Some bloom-forming cyanobacteria (i.e., Microcystis spp., Planktothrix spp.) employ gas vacuoles to move vertically in the water column. Bloom-forming cyanobacteria also range in morphology including examples of coccoid cells of Microcystis which can form aggregates or colonies (Holt et al., 1994) or filaments (i.e., Planktothrix spp.). These characteristics hinder cell counts and biovolume estimates. For instance, highly variable annual biovolume of Microcystis was observed in a multi-year study in Lake Erie and large Microcystis colonies rely on abundance estimates from colony measurements rather than direct cell counts (Bridgeman et al., 2013). Based on relative abundance in our amplicon sequencing data, cyanobacteria accounted for $<\sim 10 \%$ of the sequences recovered from the sediments (Fig. 1). In the water column, sequences affiliated with cyanobacteria ranged from $\sim 10$ to $55 \%$ of the total sequences recovered. In contrast, $\mathrm{qPCR}$ assays indicate cyanobacteria comprise 0.04 to $2.5 \%$ of the total sediment microbial community (all 16S rRNA gene sequences). In the water column, gene copies of cyanobacterial $16 \mathrm{~S}$ rRNA ranged from $2.2 \%$ of the total community to $73 \%$ (Fig. S1). The amplicon data likely overestimate the relative abundance of cyanobacteria because the number of Archaea are underestimated with the primer set we employed. Similarly, the cyanobacterial $16 \mathrm{~S}$ rRNA primers can amplify 16S rRNA genes from other bacteria but do not seem to amplify chloroplast $16 \mathrm{~S}$ rRNA gene sequences (T.L. Hamilton, unpublished). And, our data do not account for variation in the number of rRNA gene sequences per genome (Acinas et al., 2004). However, the amplicon data provide speciesspecific information in a single reaction where a similar qPCR method would require multiple primer 


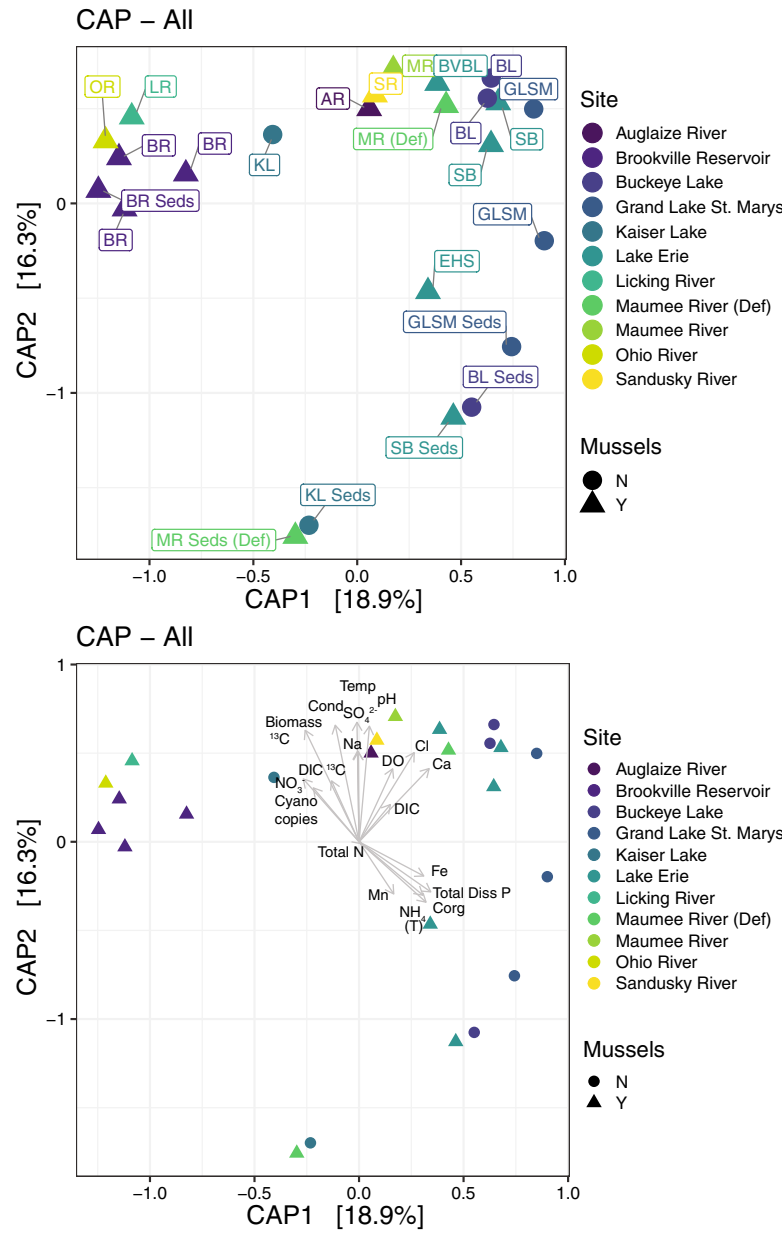

Fig. 7 Constrained ordination of environmental variables and the community composition for the total microbial community (16S rRNA, CAP - All) and for the cyanobacterial fraction only (CAP-Cyanobacteria). The ordination axes were constrained to linear combinations of environmental variables and then the environmental scores were plotted onto the ordination (bottom panel). Labels are removed in the bottom panel for clarity.

sets and assays and conversion of qPCR results to cell counts is not straightforward (Rinta-Kanto et al., 2005). A combined approach employing quantification of Microcystis-specific 16S rRNA genes and $m c y D$, a microcystin toxin synthetase gene, can facilitate determining the abundance of toxic Microcystis as has been demonstrated in Lake Erie (RintaKanto et al., 2005). However, this method is limited by primer sets specific for each bloom-forming and toxinproducing taxa. A detailed framework for relating amplicon data to biomass abundance could prove useful for identifying and quantifying specific bloomforming cyanobacteria. Regardless, our data are
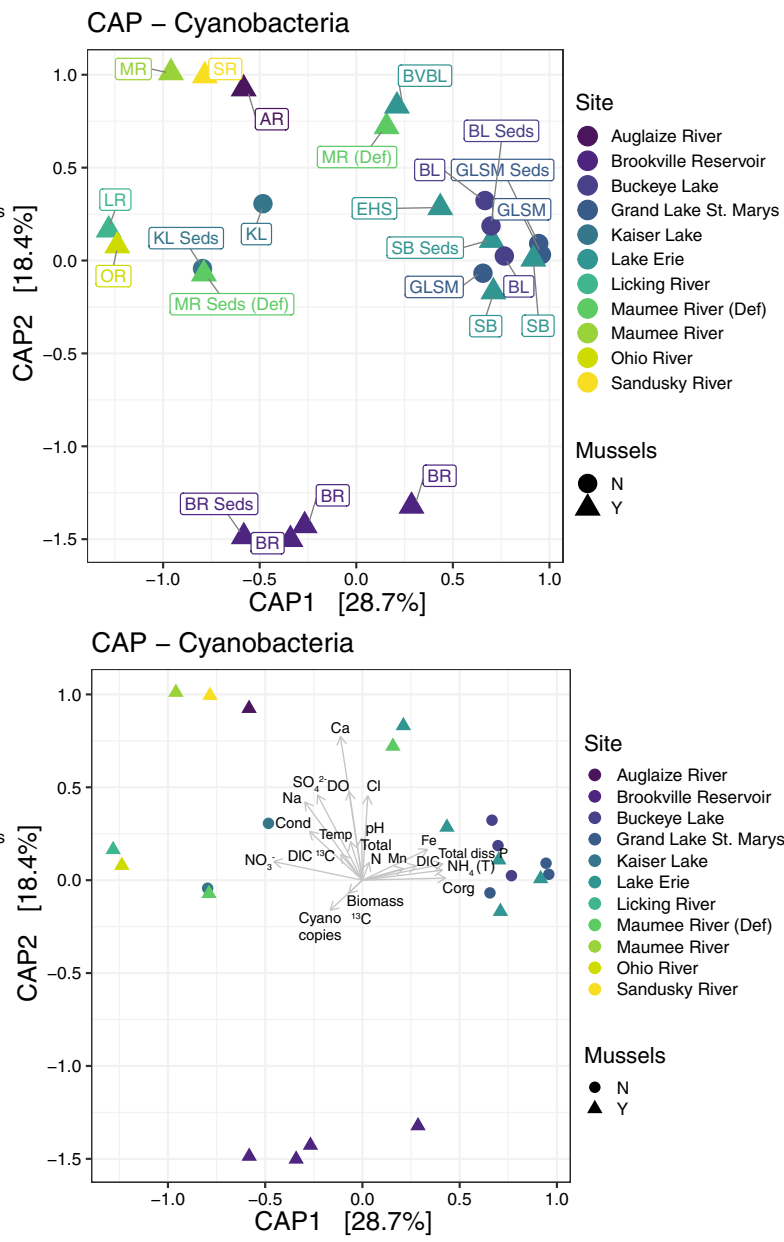

Cyano copies: abundance of the cyanobacterial 16S rRNA genes determined by qPCR; Seds sediment samples. Geochemical results are reported in Table 1. Abbreviations: $A R$ Auglaize River, $B R$ Brookville Reservoir, $B L$ Buckeye Lake, $B V B L$ Bay View Boat Launch, EHSP East Harbor State Park, GLSM Grand Lake St. Marys, $K L$ Kaiser Lake, $L R$ Licking River, $M R$ Maumee River, OR Ohio River, $S B$ Sandusky Bay

consistent with previous studies that have observed an increase in cyanobacterial biomass with nutrient input (Lürling et al., 2017): our data indicate cyanobacteria were abundant-particularly in the water column of the bloom-impacted lakes and reservoirs in this study. The decrease in cyanobacterial abundance in the sediments might indicate some consumption of biomass in the water column (and sediments). Further studies are required to determine sedimentation rates of bloom biomass and the potential for remineralization of biomass throughout bloom progression. 
Stable isotopes—carbon and nitrogen cycling

Cyanobacteria are typically a large fraction of total biomass in eutrophic lakes (Van Dam et al., 2018) and were abundant in our samples (Figs. 1, 2; Fig. S1). As a result, they likely influence carbon and other biogeochemical cycles. Here, we examined carbon and nitrogen isotope systematics in reservoirs impacted by cyanoHABs (Buckeye Lake and Grand Lake St. Marys) where, as of 2015, there had been no reports of invasive mussel species recovered (USGS website; Ohio DNR) and lakes impacted by both cyanoHABs and invasive mussel species (Brookville Lake and Sandusky Bay in Lake Erie). Buckeye Lake and Grand Lake St. Marys are reservoirs which experience cyanoHABs annually due to anthropogenic input of $\mathrm{P}$ and fixed $\mathrm{N}$ from surrounding urban and agricultural land use. Cyanotoxins have been reported, with average microcystin concentration levels well above $1 \mu \mathrm{g} / \mathrm{l}$ (Wolf \& Klaiber, 2016). Brookville Lake and Sandusky Bay in Lake Erie also experience cyanoHABs due at least in part to anthropogenic input of $\mathrm{P}$ and fixed $\mathrm{N}$ and invasive mussel species have been documented in Brookville Lake and Sandusky Bay (i.e., Dreissena spp., USGS; Ohio DNR).

\section{Carbon isotopes}

Seston carbon concentrations in the water column of both Grand Lake St. Marys and Buckeye Lake were the highest of all sites sampled, exceeding $1000 \mu \mathrm{mol}$ $\mathrm{C} / \mathrm{l}$, consistent with Secchi disk depths of 18 and $12 \mathrm{~cm}$, respectively (Figs. 4, 5; Table 1). DIC, seston, DOC, and sediment organic $\mathrm{C} \delta^{13} \mathrm{C}$ values were more positive in Grand Lake St. Marys and Buckeye Lake relative to sites with invasive mussel species (discussed below). We hypothesize that this heavier $\mathrm{C}$ signal is due to lower discrimination against isotopically heavy $\mathrm{C}$ from the DIC pool due to high productivity by bloom-driven photosynthesis. Seston C concentrations at Brookville Lake and Sandusky Bay were lower than Grand Lake St. Marys and Buckeye Lake, with associated Secchi disk depths of $110 \mathrm{~cm}$ and $24 \mathrm{~cm}$, respectively (Figs. 4, 5). The more negative DIC and seston $\delta^{13} \mathrm{C}$ values at Brookville Lake and Sandusky Bay likely reflect consumption of biomass by heterotrophs, including the diverse heterotroph microbes recovered in our amplicon studies and mussels, and subsequent respiration of isotopically light $\mathrm{CO}_{2}$ because the $\delta^{13} \mathrm{C}$ values with increasing proportion of $\mathrm{CO}_{2}$ from respiration (Schleser \& Jayasekera, 1985).

\section{Nitrogen isotopes}

In general, more positive $\delta^{15} \mathrm{~N}$ values are associated with nitrogen loss via denitrification which is expected to be the dominant biologically mediated nitrogen removal pathway in freshwater ecosystems (Seitzinger et al., 2006). Denitrifiers are taxonomically diverse and include examples of bacteria, archaea, and eukaryotes and potential denitrifiers are represented in our data set. In our samples, all $\delta^{15} \mathrm{~N}$ values were positive-the isotopically lightest $\delta^{15} \mathrm{~N}$ values were found at Buckeye Lake, with a sediment $\delta^{15} \mathrm{~N}$ value of $6.21 \%$ while lakes and reservoirs impacted by invasive mussels had more positive $\delta^{15} \mathrm{~N}$ values (Table 1 ). For instance, Grand Lake St. Marys had the most positive values for seston (13.18\% for the surface) and sediments $(8.18 \%$ ). Buckeye Lake could receive greater input of lighter fixed $\mathrm{N}$ from either artificial fertilizer or via biological nitrogen fixation in the water column contributing $\mathrm{N}$ with $\delta^{15} \mathrm{~N}$ values closer to $\sim 0$. The $\delta^{15} \mathrm{~N}$ values for seston recovered from the Licking River and the Ohio River were the most positive in this study (16.90\%o and $18.12 \%$, respectively), suggesting denitrification is even more prevalent in the impacted rivers sampled, through input of fixed nitrogen from human waste (via discharge from wastewater treatment plants) would also have extremely positive $\delta^{15} \mathrm{~N}$ values (Cabana \& Rasmussen, 1996). Implications from recent ammonium uptake experiments (e.g., Hampel et al., 2019a) and the nitrogen stable isotope results presented here suggest coupling multiple techniques for tracing nitrogen cycling in lacustrine environments might be an important next step for better understanding nitrogen cycling and availability as influences on cyanoHABs. This is supported by previous work: even in the presence of available fixed $\mathrm{N}$, competition by specific portions of the microbial community can render fixed $\mathrm{N}$ unavailable to the rest of the community, and impact community composition and function (e.g., Hamilton et al., 2014).

Dissolved $\mathrm{P}$ and fixed $\mathrm{N}$ (e.g., $\mathrm{NO}_{3}{ }^{-}$and $\mathrm{NH}_{4}(\mathrm{~T})$ ) were typically near or below detection limits in the lakes and reservoirs sampled during periods of cyanoHABs for this study (Table 1). In these 
instances, the impact of cyanobacterial blooms (and a key competition strategy of bloom-forming cyanobacteria) is the proliferation of populations in the water column that effectively capitalizes on nutrient enrichment. Indeed, depletion of bioavailable nitrogen has been observed in Sandusky Bay during late summer coincident with cyanoHABs (Chaffin et al., 2018; Salk et al., 2018) as well as increasing rates of ammonium uptake (Hampel et al., 2019a). In previous studies of Lake Erie, Planktothrix spp. persisted in N-limited bays and tributaries (Conroy et al., 2007; Kutovaya et al., 2012; Davis et al., 2015) likely due the ability of these populations to scavenge fixed $\mathrm{N}$ (Conroy et al., 2007). The abundance of Planktothrix spp. in our sample sites coupled to low levels of fixed nitrogen suggest our samples were collected at a time that coincided with enough fixed nitrogen available for Planktothrix spp. to outcompete other bloom-forming cyanobacteria. It should be noted that there are strains of Planktothrix that have the capacity for nitrogen fixation (Pancrace et al., 2017). These observations coupled to our 16S rRNA amplicon data indicating diverse populations of heterotrophic bacteria coincident with cyanoHABs suggest complex competitive anabolic and catabolic trophic interactions in cyanoHABs.

During a bloom period, bloom-forming cyanobacteria can outcompete non-bloom-forming microorganisms for fixed $\mathrm{N}$ as well as $\mathrm{P}$, maintaining high biomass loads in the water column and effectively removing $\mathrm{P}$ and fixed $\mathrm{N}$ from the water column (Table 1). Thus, while a lake may be designated eutrophic due to loading from anthropogenically driven input of $\mathrm{P}$ and fixed $\mathrm{N}$ and may have measurable and excessive levels of dissolved $\mathrm{P}$ and fixed $\mathrm{N}$ during periods of the year, cyanoHABs can act to reduce dissolved $\mathrm{P}$ and fixed $\mathrm{N}$ in the water column through sequestration into bloom biomass. Measurements of total or particulate $\mathrm{N}$ and $\mathrm{P}$ would likely have reflected substantial nutrient concentrations associated with the eutrophic status of the ecosystems. Management strategies for mitigating cyanoHABs include more efficient removal of fixed $\mathrm{N}$ and reduction of $\mathrm{N}+\mathrm{P}$ loading (Paerl et al., 2011; Hampel et al., 2019b); however, varying combinations of nutrients, including $\mathrm{N}$ and $\mathrm{P}$, along with elevated temperatures can promote different taxa of bloom-forming cyanobacteria (Jankowiak et al., 2019). Regardless, our data indicate a higher removal of fixed $\mathrm{N}$ in systems impacted by cyanoHABs and invasive mussels, suggesting a beneficial role for mussels in terms of $\mathrm{N}$.

\section{Potential impacts on carbon sequestration}

Cyanobacteria can use bicarbonate in addition to $\mathrm{CO}_{2}$, via the enzyme carbonic anhydrase which catalyzes the conversion of $\mathrm{HCO}_{3}{ }^{-}$to $\mathrm{CO}_{2}$ and $\mathrm{OH}^{-}$(thus affecting $\mathrm{pH}$ ). However, $\mathrm{CO}_{2}$ is the preferred substrate for photoautotrophic Cyanobacteria. During blooms, cyanobacterial primary productivity decreases $p \mathrm{CO}_{2}$, increasing $\mathrm{pH}$ ( $\mathrm{pH}$ values $>8.5$, see Fig. 4) and shifting speciation from $\mathrm{CO}_{2}$ to $\mathrm{HCO}_{3}{ }^{-}$or $\mathrm{CO}_{3}{ }^{-}$. To overcome $\mathrm{CO}_{2}$ limitation, Cyanobacteria employ efficient carbon concentrating mechanisms which enable them to consume $\mathrm{HCO}_{3}{ }^{-}$or $\mathrm{CO}_{3}{ }^{-}$(Van Dam et al., 2018). Here, we assume photosynthesis from water column algal and cyanobacterial carbon fixation is the dominating factor imparting the $\delta^{13} \mathrm{C}$ values of organic carbon. We acknowledge that this is a simplification as biotic and abiotic factors including the carbon concentrating reaction, growth rate, photochemical degradation, and $p \mathrm{CO}_{2}$ can influence $\delta^{13} \mathrm{C}$ values of organic carbon in eutrophic lakes (MoralesWilliams et al., 2017; Van Dam et al., 2018). However, given the abundance of cyanobacteria during cyanoHABs including in our data set (Fig. 1; Fig. S1), it is reasonable to assume that photosynthesis in the water column is the major factor imparting the $\delta^{13} \mathrm{C}$ values of organic carbon. Indeed, in Lake Taihu, $p \mathrm{CO}_{2}$ was below equilibrium with the atmosphere at the peak of the cyanoHAB (Van Dam et al., 2018).

Earth-system modelers have long recognized that carbon isotope values of organic carbon, inorganic carbon, primary system inputs, and estimates of carbon fractionation during carbon fixation can be used to estimate the fraction of inorganic carbon buried as organic carbon (e.g., Hayes et al., 1999). While a likely over-simplification for lakes, it is useful to use this relationship for a first-order comparison between lakes, and for placing short-term lake carbon sequestration in the context of ocean carbon sequestration. Using Eq. 3 (see methods) and the assumptions discussed above, the fraction of DIC removed from the surface and buried as organic carbon in the sediments at Grand Lake St. Marys and Buckeye might be $50-300 \%$ over that of the $\sim 20 \%$ assumed modern average global value for the world's oceans 
(Fig. 5; Hayes et al., 1999; Schrag et al., 2013). This is consistent with recent work suggesting lakes and reservoirs sequester up to five times as much carbon as the world's oceans (Dean \& Gorham, 1998; Cole et al., 2007; Downing et al., 2008, Tranvik et al., 2009). For lakes impacted by cyanoHABs and invasive mussels, the fraction of DIC removed could be much lower (Fig. 8). Combining these data with surface sediment carbon (presented in the Supporting Information), our data suggest shallow eutrophic lakes or reservoirs impacted by blooms are efficient at removing organic $\mathrm{C}$ from the water column, and thus potentially efficient at sequestering $\mathrm{C}$. While the mechanisms of carbon fixation and organic carbon production are effectively the same for lakes/reservoirs and the ocean, the time scales for burial of organic carbon into sediments and sequestration of that carbon away from the carbon cycle for lakes/reservoirs are much shorter than that of the ocean. Reservoirs and lakes are effective transient bodies on continental surfaces with lifespans measured in hundreds to tens of thousands of years. Burial of organic carbon in sediments on ocean crust can sequester organic carbon for millions to hundreds of millions of years, and burial of organic carbon in ocean sediments deposited on continental crust can sequester organic carbon for millions to billions of years. However, these differences are effectively moot when considering human time scales in relation to anthropogenic global climate change.

\section{Conceptual model}

Our data suggest that the presence or absence of invasive mussel species is not correlative to the composition of cyanobacteria in cyanoHABs. However, we acknowledge that our single time point samples do not capture temporal or seasonal variability in bloom community structure. Regardless, we examined sites with and without invasive mussel species that experience cyanoHABs annually to build a framework to assess how the presence of invasive mussels may affect carbon sequestration in eutrophic systems. We constructed a conceptual model for the movement and sequestration of carbon in the different types of lakes and reservoirs sampled in this study (Fig. 9, see SOM for description of the model). Using this framework, our data suggest lakes and reservoirs that have experienced eutrophication that drives cyanoHABs such as Buckeye Lake and Grand Lake

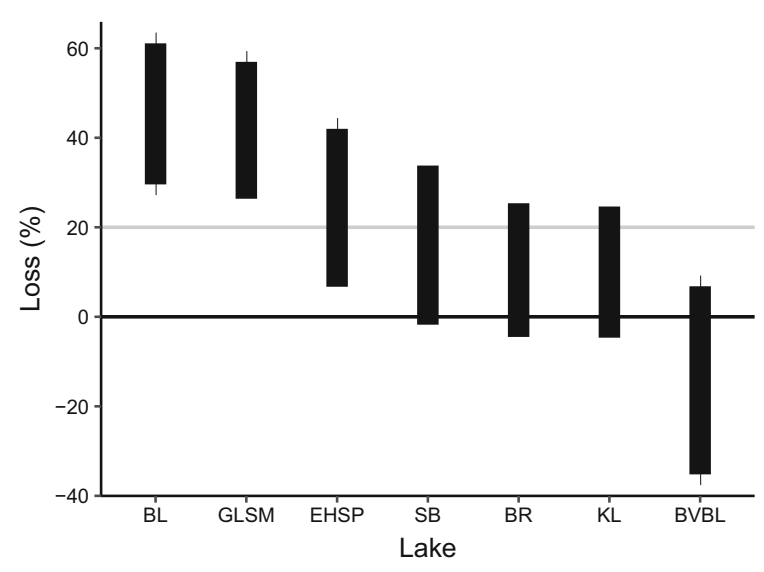

Fig. 8 Percent carbon removed in lakes and reservoirs. Boxplots represent analytical error. Gray line indicates average carbon removal in the global oceans. Abbreviations: $B L$ Buckeye Lake*, GLSM Grand Lake St. Marys*, EHSP East Harbor State Park, $S B$ Sandusky Bay, BR Brookville Reservoir, $K L$ Kaiser Lake*, $B V B L$ Bay View Boat Launch, * lakes with cyanoHABs only

St. Marys (GLSM) have potential for efficient sequestration of both $\mathrm{C}_{\text {org }}$ and $\mathrm{C}_{\text {carb }}$ (see SOM for further discussion). However, the $\mathrm{C}_{\text {org }}$ sediment concentrations at those two lakes (4.14 to $4.17 \%$; Table 1) indicate an approximate three-fold reduction in $\mathrm{C}_{\text {org }}$ burial compared to an average of surface sediments in 20 lakes across Minnesota (Dean, 1999). Furthermore, the $\mathrm{C}_{\text {carb }}$ sediment concentrations $(1.99 \%$ at Buckeye Lake and $2.17 \%$ at GLSM; Table 1) indicate less carbonate burial compared to an average of $3.13 \% \mathrm{C}$ as $\mathrm{CaCO}_{3}$ (Dean, 1999). The data reported by Dean (1999) were for lakes associated with glacial till (similar to those in Ohio), but only $25 \%$ of the lakes had bedrock with carbonate rocks, suggesting there may be differences in the geochemistry of water delivered to the other Minnesota lakes. Lakes and reservoirs with cyanoHABs which have also been colonized by invasive mussel species (such as Brookville Lake and Sandusky Bay, Lake Erie) appeared to exhibit a reduced capacity for carbon sequestration compared to the cyanoHAB only sites. Reduced burial of organic carbon is likely linked directly to consumption and respiration/metabolic breakdown of organic matter from the water column by mussels. Burial of inorganic carbon may be influenced by several factors. First, reduced cyanobacterial biomass may be related to decreased rates of photosynthetically driven calcite production due to 
decreased nucleation sites (fewer cells in the water column). Second, increased uptake of calcium by mussels for shell formation may lead to less calcium available for calcite precipitation. Finally, increased growth of mussels may lead to increased production of $\mathrm{CO}_{2}$ in the water column (due to mussel metabolism) generating carbonic acid which will react with calcite crystals in the water column to dissolve it.

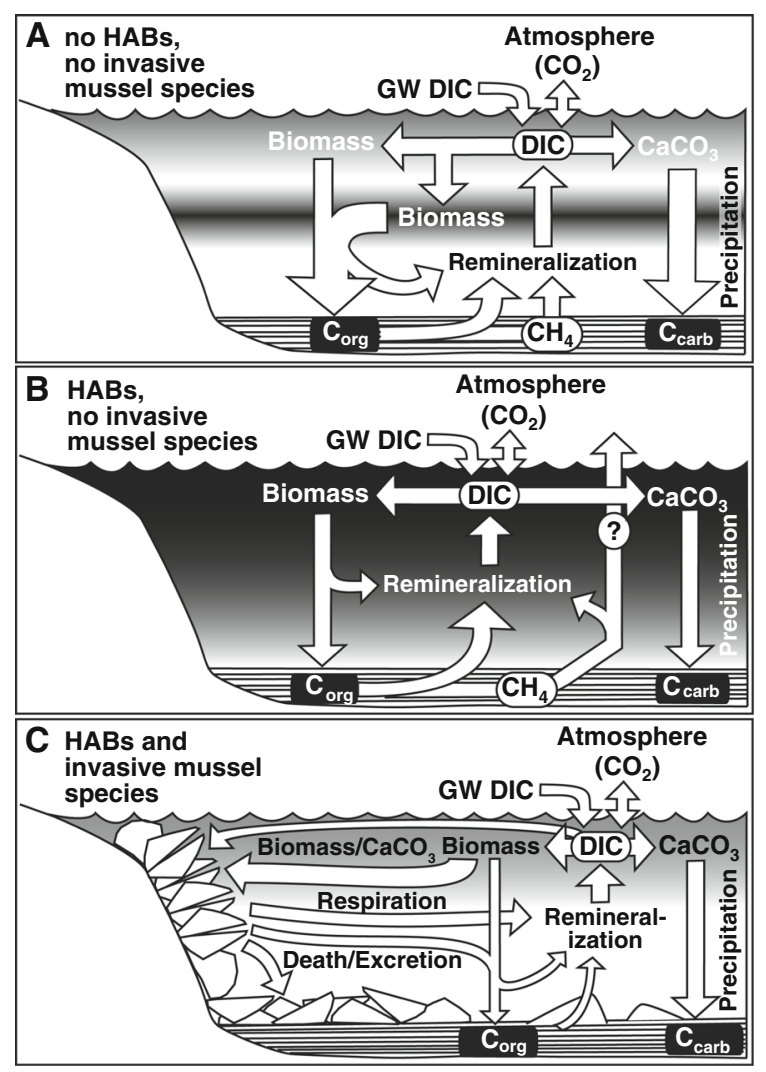

Fig. 9 Conceptual model for the flow of carbon through lakes/ reservoirs in western Ohio and eastern Indiana, USA. CyanoHABs eutrophication-induced cyanobacterial blooms, $D I C$ dissolved inorganic carbon, $G W$ groundwater. Water column shading indicates density of suspended biomass, with darker shading representing higher density. Arrow widths represent qualitative differences between representative models. Lake/reservoir cross sections are not to scale. A Carbon flow through lakes/reservoirs that do not experience cyanoHABs and do not have invasive mussel species present. B Carbon flow through lakes/reservoirs that experience cyanoHABs, but do not have invasive mussel species present. $\mathbf{C}$ Carbon flow through lakes/reservoirs that experience cyanoHABs and have invasive mussel species present

\section{Limitations of this study}

The presence or absence of invasive mussel species was not correlative to the composition of cyanobacteria in cyanoHABs in our single time point samples; however, we acknowledge our samples do not capture temporal or seasonal variability in bloom community structure. The treatment of invasive mussel species was simplified to yes/no, assuming presence equates complete colonization of the water body in question and negating potential influence of relative mussel population. We also assume mussels contribute to heterotrophic activity in the ecosystems where there are present. In addition, our sample sites-13 sites across lakes, rivers, and reservoirs - vary in numerous ways including depth, volume, residence time, internal and external nutrient loading, the duration, frequency, and severity of cyanoHABs, food web structure, mussel density, and invasion history. Finally, our model simplifies carbon cycling (we ignore retention time, sedimentation rates, morphometry, catchment sizes, etc.). Indeed, the combination of environmental stressors including, invasive mussels, that lead to cyanoHAB proliferation and altered carbon cycling and burial require further testing with a more comprehensive treatment of lakes and reservoirs.

\section{Conclusions and outlook}

Analyses of physicochemistry and community composition of eutrophic lake/reservoir and river sites in western Ohio, eastern Indiana, and northern Kentucky indicate that invasive mussel species do not necessarily translate into large differences in microbial community composition during cyanoHABs. However, we did observe large changes in the carbon stable isotope compositions of water and sediment carbon pools between systems impacted by cyanoHABs versus both cyanoHABs and invasive mussels. From our assessment, we predict a decrease in carbon sequestration potential with increasing occurrence of invasive mussel species in eutrophic ecosystems. Future studies including deep sediment cores could constrain the relationship between surface sediment burial to deeper burial and sequestration of $\mathrm{C}$ in these systems as they progress from natural to anthropogenically influenced/ eutrophic and/or colonized by invasive mussel species. There is also a paucity of data on the abundance 
of invasive mussels, both spatially and temporally, in impacted water. Our 16S rRNA amplicon studies bolster other studies that suggest complex trophic level interactions in the water column that may affect bloom severity and longevity based on competition for $\mathrm{N}$ and $\mathrm{P}$. The effects of these interactions on bloom toxicity are largely uncharacterized. In summary, our data highlight potential long-term effects of eutrophication and in particular, harmful cyanobacterial blooms and invasive mussels, on carbon burial which warrants further study.

Acknowledgements TLH and JRH graciously acknowledge support from the University of Cincinnati and the University of Minnesota. The authors are grateful for constructive suggestions and feedback from anonymous reviewers and the editorial staff. The authors acknowledge the Minnesota Supercomputing Institute (MSI) at the University of Minnesota for providing resources that contributed to the research results reported within this paper. We are also grateful to A. Diefendorf for access to and use of the Stable Isotope Geochemistry Lab in the Department of Geology at the University of Cincinnati.

Open Access This article is licensed under a Creative Commons Attribution 4.0 International License, which permits use, sharing, adaptation, distribution and reproduction in any medium or format, as long as you give appropriate credit to the original author(s) and the source, provide a link to the Creative Commons licence, and indicate if changes were made. The images or other third party material in this article are included in the article's Creative Commons licence, unless indicated otherwise in a credit line to the material. If material is not included in the article's Creative Commons licence and your intended use is not permitted by statutory regulation or exceeds the permitted use, you will need to obtain permission directly from the copyright holder. To view a copy of this licence, visit http://creativecommons.org/licenses/by/4.0/.

\section{References}

Abrantes, N., S. C. Antunes, M. J. Pereira \& G. Gonçalves, 2006. Seasonal succession of cladocerans and phytoplankton and their interactions in a shallow eutrophic lake (Lake Vela, Portugal). Acta Oecologica 29: 54-64.

Acinas, S. G., L. A. Marcelino, V. Klepac-Ceraj \& M. F. Polz, 2004. Divergence and redundancy of $16 \mathrm{~S}$ rRNA sequences in genomes with multiple $r r n$ operons. Journal of Bacteriology 186: 2629-2635.

Alexander, T. J., P. Vonlanthen \& O. Seehausen, 2017. Does eutrophication-driven evolution change aquatic ecosystems? Philosophical Transactions of the Royal Society B Biological Sciences 372: 20160041.

Apprill, A., S. McNally, R. Parsons \& L. Weber, 2015. Minor revision to V4 region of SSU rRNA 806R gene primer greatly increases detection of SAR11 bacterioplankton. Aquatic Microbial Ecology 75: 129-137.

Arnott, D. L. \& M. J. Vanni, 1996. Nitrogen and phosphorus recycling by the zebra mussel (Dreissena polymorpha) in the western basin of Lake Erie. Canadian Journal of Fisheries and Aquatic Sciences 53: 646-659.

Berry, M. A., T. W. Davis, R. M. Cory, M. B. Duhaime, T. H. Johengen, G. W. Kling, J. A. Marino, P. A. Den Uyl, D. Gossiaux, G. J. Dick \& V. J. Denef, 2017. Cyanobacterial harmful algal blooms are a biological disturbance to Western Lake Erie bacterial communities. Environmental Microbiology 19: 1149-1162.

Blom, J. F., B. Bister, D. Bischoff, G. Nicholson, G. Jung, R. D. Süssmuth \& F. Jüttner, 2003. Oscillapeptin J, a new grazer toxin of the freshwater cyanobacterium Planktothrix rubescens. Journal of Natural Products 66: 431-434.

Bridgeman, T. B., J. D. Chaffin \& J. E. Filbrun, 2013. A novel method for tracking western Lake Erie Microcystis blooms, 2002-2011. Journal of Great Lakes Research 39: 83-89.

Cabana, G. \& J. B. Rasmussen, 1996. Comparison of aquatic food chains using nitrogen isotopes. Proceedings of the National Academy of Sciences of the United States of America 93: 10844-10847.

Cai, H. Y., Z. S. Yan, A. J. Wang, L. R. Krumholz \& H. L. Jiang, 2013. Analysis of the attached microbial community on mucilaginous cyanobacterial aggregates in the eutrophic Lake Taihu reveals the importance of Planctomycetes. Microbial Ecology 66: 73-83.

Caporaso, J. G., C. L. Lauber, W. A. Walters, D. Berg-Lyons, J. Huntley, N. Fierer, S. M. Owens, J. Betley, L. Fraser, M. Bauer, M. Gormely, J. A. Gilbert, J. Smith \& R. Knight, 2012. Ultra-high-throughput microbial community analysis on the Illumina HiSeq and MiSeq platforms. The ISME Journal 6: 1621-1624.

Chaffin, J. D., T. W. Davis, D. J. Smith, M. M. Baer \& G. J. Dick, 2018. Interactions between nitrogen form, loading rate, and light intensity on Microcystis and Planktothrix growth and microcystin production. Harmful Algae 73: 84-97.

Chen, K., J. Allen \& J. Lu, 2017. Community structures of phytoplankton with emphasis on toxic cyanobacteria in an Ohio Inland Lake during Bloom Season. Journal of Water Resources and Protection 9: 1299-1318.

Choquette, A. F., R. M. Hirsch, J. C. Murphy, L. T. Johnson \& R. B. Confesor Jr., 2019. Tracking changes in nutrient delivery to western Lake Erie: approaches to compensate for variability and trends in streamflow. Journal of Great Lakes Research 45: 21-39.

Christiansen, G., J. Fastner, M. Erhard, T. Borner \& E. Dittmann, 2003. Microcystin biosynthesis in Planktothrix: genes, evolution, and manipulation. Journal of Bacteriology 185: 564-572.

Cole, J. J., Y. T. Prairie, N. F. Caraco, W. H. McDowell, L. J. Travnik, R. G. Strigel, C. M. Duarte, P. Kortelainen, J. A. Downing, J. J. Middleburg \& J. Melack, 2007. Plumbing the global carbon cycle: integrating inland waters into the terrestrial carbon budget. Ecosystems 10: 172-185.

Comeau, A. M., W. K. W. Li, J.-É. Tremblay, E. C. Carmack \& C. Lovejoy, 2011. Arctic Ocean microbial community structure before and after the 2007 record sea ice minimum. PLoS ONE 6: e27492. 
Conroy, J. D., W. J. Edwards, R. A. Pontius, D. D. Kane, H. Zhang, J. F. Shea, J. N. Richey \& D. A. Culver, 2005. Soluble nitrogen and phosphorus excretion of exotic freshwater mussels (Dreissena spp.): potential impacts for nutrient remineralisation in western Lake Erie. Freshwater Biology. 50: 1146-1162.

Conroy, J. D., E. L. Quinlan, D. D. Kane \& D. A. Culver, 2007. Cylindrospermopsis in Lake Erie: testing its association with other cyanobacterial genera and major limnological parameters. Journal of Great Lakes Research 33: 519-535.

Conroy, J. D., D. D. Kane, R. D. Briland \& D. A. Culver, 2014. Systemic, early-season Microcystis blooms in western Lake Erie and two of its major agricultural tributaries (Maumee and Sandusky Rivers). Journal of Great Lakes Research 40: 518-523.

Davis, T. W., F. Koch, M. A. Marcoval, S. W. Wilhelm \& C. J. Gobler, 2012. Mesozooplankton and microzooplankton grazing during cyanobacterial blooms in the western basin of Lake Erie. Harmful Algae 15: 26-35.

Davis, T. W., G. S. Bullerjahn, G. S. Tuttle, R. M. McKay \& S. B. Watson, 2015. Effects of increasing nitrogen and phosphorus concentrations on phytoplankton community growth and toxicity during Planktothrix blooms in Sandusky Bay, Lake Erie. Environmental Science \& Technology 49: 7197-7207.

Dean, W. E., 1999. The carbon cycle and biogeochemical dynamics in lake sediments. Journal of Paleontology 21: 375-393.

Dean, W. E. \& E. Gorham, 1998. Magnitude and significance of carbon burial in lakes, reservoirs, and peatlands. Geology 26: 535-538.

Dhariwal, A., J. Chong, S. Habib, I. King, L. B. Agellon \& J. Xia, 2017. MicrobiomeAnalyst - a web-based tool for comprehensive statistical, visual and meta-analysis of microbiome data. Nucleic Acids Research 45: W180W188.

Downing, J. A., J. J. Cole, J. J. Middelburg, R. G. Striegl, C. M. Duarte, P. Kortelainen, Y. T. Prairie \& K. A. Laube, 2008. Sediment organic carbon burial in agriculturally eutrophic impoundments over the last century. Global Biogeochemical Cycles 22: GB1018.

Duc, N. T., P. Crill \& D. Bastviken, 2010. Implications of temperature and sediment characteristics on methane formation and oxidation in lake sediments. Biogeochemistry 100: 185-196.

Edgar, R. C., B. J. Haas, J. C. Clemente, C. Quince \& R. Knight, 2011. UCHIME improves sensitivity and speed of chimera detection. Bioinformatics 27: 2194-2200.

Fleckenstein, J. H., S. Krause, D. M. Hannah \& F. Boano, 2010. Groundwater-surface water interactions: new methods and models to improve understanding of processes and dynamics. Advances in Water Resources 33: 1291-1295.

Fogg, G. E., 1969. The physiology of an algal nuisance. Proceedings of the Royal Society B 173: 175-189.

Gobler, C. J., T. W. Davis, S. N. Deonarine, M. A. Saxton, P. J. Lavrentyev, F. J. Jochem \& S. W. Wilhelm, 2008. Grazing and virus-induced mortality of microbial populations before and during the onset of annual hypoxia in Lake Erie. Aquatic Microbial Ecology 51: 117-128.

Goedkoop, W., R. Naddafi \& U. Grandin, 2011. Retention of N and $\mathrm{P}$ by zebra mussels (Dreissena polymorpha Pallas) and its quantitative role in the nutrient budget of eutrophic Lake Ekoln, Sweden. Biological Invasions 13: 1077-1086.

Grasset, C., R. Mendonça, G. Villamor Saucedo, D. Bastviken, F. Roland \& S. Sobek, 2018. Large but variable methane production in anoxic freshwater sediment upon addition of allochthonous and autochthonous organic matter. Limnology and Oceanography 63: 1488-1501.

Halstvedt, C. B., T. Rohrlack, T. Andersen, O. Skulberg \& B. Edvardsen, 2007. Seasonal dynamics and depth distribution of Planktothrix spp. in Lake Steinsfjorden (Norway) related to environmental factors. Journal of Plankton Research 29: 471-482.

Hamilton, T. L., J. W. Peters, M. L. Skidmore \& E. S. Boyd, 2013. Molecular evidence for an active endogenous microbiome beneath glacial ice. The ISME Journal 7: 1402-1412.

Hamilton, T. L., E. Koonce, A. Howells, J. R. Havig, T. Jewell, J. de la Torre, J. W. Peters \& E. S. Boyd, 2014. Competition for ammonia influences the structure of chemotrophic communities in geothermal springs. Applied and Environmental Microbiology 80: 653-661.

Hampel, J. J., M. J. McCarthy, M. Neudeck, G. S. Bullerjahn, R. M. L. McKay \& S. L. Newell, 2019a. Ammonium recycling supports toxic Planktothrix blooms in Sandusky Bay, Lake Erie: evidence from stable isotope and metatranscriptome data. Harmful Algae 81: 42-52.

Hampel, J. J., M. J. McCarthy, W. S. Gardner, L. Zhang, H. Xu, G. Zhu \& S. E. Newell, 2019b. Nitrification and ammonium dynamics in Taihu Lake, China: seasonal competition for ammonium between nitrifiers and cyanobacteria. Biogeosciences 15: 733-748.

Harke, M. J., T. W. Davis, S. B. Watson \& C. J. Gobler, 2016. Nutrient-controlled niche differentiation of Western Lake Erie cyanobacterial populations revealed via metatranscriptomic surveys. Environmental Science \& Technology 50: 604-615.

Havig, J. R., T. L. Hamilton, A. Bachan \& L. R. Kump, 2017. Sulfur and carbon isotopic evidence for metabolic pathway evolution and a four-stepped Earth system progression across the Archean and Paleoproterozoic. Earth-Science Reviews 174: 1-21.

Hayashi, M. \& D. O. Rosenberry, 2002. Effects of ground water exchange on the hydrology and ecology of surface water. Groundwater 40: 309-316.

Hayes, J., H. Strauss \& A. Kaufman, 1999. The abundance of ${ }^{13} \mathrm{C}$ in marine organic matter and isotopic fractionation in the global biogeochemical cycle of carbon during the past 800 Ma. Chemical Geology 161: 103-125.

Heathcote, A. J. \& J. A. Downing, 2012. Impacts of eutrophication on carbon burial in freshwater lakes in an intensively agricultural landscape. Ecosystems 15: 60.

Heathcote, A. J., N. J. Anderson, Y. T. Prairie, D. R. Engstrom \& P. A. del Giorgio, 2015. Large increases in carbon burial in northern lakes during the Anthropocene. Nature Communications 6: 10016.

Hecky, R. E., R. E. H. Smith, D. R. Barton, S. J. Guildford, W. D. Taylor, M. N. Charlton \& T. Howell, 2004. The nearshore phosphorus shunt: a consequence of ecosystem engineering by dreissenids in the Laurentian Great Lakes. Canadian Journal of Fisheries and Aquatic Sciences 61: 1285-1293. 
Higgins, S. N. \& M. J. Vander Zanden, 2010. What a difference a species makes: a meta-analysis of dreissenid mussel impacts on freshwater ecosystems. Ecological Monographs 80: 179-196.

Holt, J. G., N. R. Krieg, P. H. A. Sneath, J. T. Staley \& S. T. Williams, 1994. Group 11. Oxygenic phototrophic bacteria. In Hensyl, W. R. (ed.), Bergey's Manual of Determinative Bacteriology, 9th ed. Williams \& Wilkins, Baltimore: $377-425$.

Huang, C., L. Zhang, Y. Li, C. Lin, T. Huang, M. Zhang, A. X. Zhu, H. Yang \& X. Wang, 2018. Carbon and nitrogen burial in a plateau lake during eutrophication and phytoplankton blooms. Science of the Total Environment 616: 296-304.

Huisman, J. M., H. C. P. Matthijs \& P. M. Visser, 2005. Harmful Cyanobacteria., Springer Aquatic Ecology Series 3 Springer, Dordrecht.

Jankowiak, J., T. Hattenrath-Lehmann, B. J. Kramer, M. Ladds \& C. J. Gobler, 2019. Deciphering the effects of nitrogen, phosphorus, and temperature on cyanobacterial bloom intensification, diversity, and toxicity in western Lake Erie. Limnology and Oceanography 64: 1347-1370.

Komárek, J. \& J. Komárková, 2004. Taxonomic review of the cyanoprokaryotic genera Planktothrix and Planktothricoides. Czech Phycology Olomouc 4: 1-18.

Kovalenko, K. E., E. D. Reavie, J. D. Allan, M. Cai, S. D. P. Smith \& L. B. Johnson, 2017. Pelagic phytoplankton community change-points across nutrient gradients and in response to invasive mussels. Freshwater Biology 62: 366-381.

Kozich, J. J., S. L. Westcott, N. T. Baxter, S. K. Highlander \& P. D. Schloss, 2013. Development of a dual-index sequencing strategy and curation pipeline for analyzing amplicon sequence data on the MiSeq Illumina sequencing platform. Applied and Environmental Microbiology 79: 5112-5120.

Kutovaya, O. A., R. M. McKay, B. Beall, S. W. Wilhelm, D. Kane, J. Chaffin, T. Bridgeman \& G. S. Bullerjahn, 2012. Evidence against fluvial seeding of recurrent toxic blooms of Microcystis spp. in Lake Erie's western basin. Harmful Algae 15: 71-77.

Lampert, W. \& U. Sommer, 1997. Limnoecology: The Ecology of Lakes and Streams. Oxford University Press, New York.

Lürling, M., F. van Oosterhout \& E. Faassen, 2017. Eutrophication and warming boost cyanobacterial biomass and microcystins. Toxins 9: 64 .

Mariotti, A., J. Germon, P. Hubert, P. Kaiser, R. Letolle, A. Tardieux \& P. Tardieux, 1981. Experimental determination of nitrogen kinetic isotope fractionation: some principles; illustration for the denitrification and nitrification processes. Plant and Soil 62: 413-430.

McKay, R. M. L., T. Tuttle, L. A. Reitz, G. S. Bullerjahn, W. R. Cody, A. J. McDowell \& T. W. Davis, 2018. Early onset of a microcyst in-producing cyanobacterial bloom in an agriculturally-influenced Great Lakes tributary. Journal of Oceanology and Limnology 36: 112-125.

McMahon, K. D. \& E. K. Read, 2013. Microbial contributions to phosphorus cycling in eutrophic lakes and wastewater. Annual Review of Microbiology 67: 199-219.

McMurdie, P. J. \& S. Holmes, 2013. phyloseq: an R package for reproducible interactive analysis and graphics of microbiome census data. PLoS ONE 8: e61217.
Michalak, A. M., E. J. Anderson, D. Beletsky, S. Boland, N. S. Bosch, T. B. Bridgeman, J. D. Chaffin, K. Cho, R. Confesor, I. Daloglu, J. V. DePinto, M. A. Evans, G. L. Fahnenstiel, L. He, J. C. Ho, L. Jenkins, T. H. Johengen, K. C. Kuo, E. LaPorte, X. Liu, M. R. McWilliams, M. R. Moore, D. J. Posselt, R. P. Richards, D. Scavia, A. L. Steiner, E. Verhamme, D. M. Wright \& M. A. Zagorski, 2013. Record-setting algal bloom in Lake Erie caused by agricultural and meteorological trends consistent with expected future conditions. Proceedings of the National Academy of Sciences of the United States of America 110: 6448-6452.

Miles, J., 1985. The representation of flows to partially penetrating rivers using groundwater flow models. Journal of Hydrology 82: 341-355.

Morales-Williams, A. M., A. D. Wanamaker Jr. \& J. A. Downing, 2017. Cyanobacterial carbon concentrating mechanisms facilitate sustained $\mathrm{CO}_{2}$ depletion in eutrophic lakes. Biogeosciences 14: 2865-2875.

Mou, X., L. Xinxin, J. Jacob, S. Sun \& R. Heath, 2013. Metagenomic identification of bacterioplankton taxa and pathways involved in microcystin degradation in Lake Erie. PLoS ONE 8: e61890.

Nübel, U., F. Garcia-Pichel \& G. Muyzer, 1997. PCR primers to amplify 16S rRNA genes from cyanobacteria. Applied and Environmental Microbiology 63: 3327-3332.

Oksanen, J. F., G. Blanchet, M. Friendly, R. Kindt, P. Legendre, D. McGlinn, P. R. Minchin, R. B. O'Hara, G. L. Simpson, P. Solymos, M. H. H. Stevens, E. Szoecs \& H. Wagner, 2019. vegan: Community Ecology Package. R package version 2.5-4. https://CRAN.Rproject.org/package = vegan.

Ouellette, A. J. A., S. M. Handy \& S. W. Wilhelm, 2006. Toxic Microcystis is widespread in Lake Erie: PCR detection of toxin genes and molecular characterization of associated cyanobacterial communities. Microbial Ecology 51: 154-165.

Paerl, H. W., 2017. Controlling harmful cyanobacterial blooms in a climatically more extreme world: management options and research needs. Journal of Plankton Research 39: 763-771.

Paerl, H. W. \& R. S. Fulton III, 2006. Ecology of harmful cyanobacteria. In Graneli, E. \& J. Turner (eds), Ecology of Harmful Marine Algae. Springer, Berlin: 95-107.

Paerl, H. W., N. S. Hall \& E. S. Calandrino, 2011. Controlling harmful cyanobacterial blooms in a world experiencing anthropogenic and climatic-induced change. Science of the Total Environment 409: 1739-1745.

Pancrace, C., M. A. Barny, R. Ueoka, A. Calteau, T. Scalvenzi, J. Pédron, V. Barbe, J. Piel, J. F. Humbert \& M. Gugger, 2017. Insights into the Planktothrix genus: genomic and metabolic comparison of benthic and planktic strains. Scientific Reports 7: 41181.

Pizzetti, I., A. Gobet, B. M. Fuchs, R. Armann \& S. Fazi, 2011 a. Abundance and diversity of Planctomycetes in a Tyrrhenian coastal system of central Italy. Aquatic Microbial Ecology 65: 129-141.

Pizzetti, I., B. M. Fuchs, G. Gerdts, A. Wichels, K. H. Wiltshire \& R. Armann, 2011b. Temporal variability of coastal Planctomycetes clades at Kabeltonne station, North Sea. Applied and Environmental Microbiology 77: 5009-5017. 
Rinta-Kanto, J. M. \& S. W. Wilhelm, 2006. Diversity of microcystin-producing cyanobacteria in spatially isolated regions of Lake Erie. Applied and Environmental Microbiology 72: 5083-5085.

Rinta-Kanto, J. M., A. J. A. Ouellette, G. L. Boyer, M. R. Twiss, T. B. Bridgeman \& S. W. Wilhelm, 2005. Quantification of toxic Microcystis spp. during the 2003 and 2004 blooms in western Lake Erie using quantitative real-time PCR. Environmental Science \& Technology. 39: 4198-4205.

Rohwer, R. R., J. J. Hamilton, R. J. Newton \& K. D. McMahon, 2018. TaxAss: leveraging a custom freshwater database achieves fine-scale taxonomic resolution. mSphere 3 : e00327-18.

R Core Team, 2018. R: A Language and Environment for Statistical Computing. R Foundation for Statistical Computing, Vienna, Austria. https://www.R-project.org/.

Salk, K. R., G. S. Bullerjahn, R. M. L. Mckay, J. D. Chaffin \& N. E. Ostrom, 2018. Nitrogen cycling in Sandusky Bay, Lake Erie: oscillations between strong and weak export and implications for harmful algal blooms. Biogeosciences 15: 2891-2907.

Sarnelle, O., A. E. Wilson, S. K. Hamilton, L. B. Knoll \& D. F. Raikow, 2005. Complex interactions between the zebra mussel, Dreissena polymorpha, and the harmful phytoplankter, Microcystis aeruginosa. Limnology and Oceanography 50: 896-904.

Sarnelle, O., J. D. White, G. P. Horst \& S. K. Hamilton, 2012. Phosphorus addition reverses the positive effect of zebra mussels (Dreissena polymorpha) on the toxic cyanobacterium, Microcystis aeruginosa. Water Research 46: 3471-3478.

Schleser, G. H. \& R. Jayasekera, $1985 .{ }^{13} \mathrm{C}$-variations of leaves in forests as an indication of reassimilated $\mathrm{CO}_{2}$ from the soil. Oecologia 65: 536-542.

Schloss, P. D., S. L. Westcott, T. Ryabin, J. R. Hall, M. Hartmann, E. B. Hollister, A. R. Lesniewski, B. B. Oakley, D. H. Parks, C. J. Robinson, J. W. Sahl, B. Stres, G. G. Thalliner, D. J. Van Horn \& C. F. Weber, 2009. Introducing mothur: open-source, platform-independent, community-supported software for describing and comparing microbial communities. Applied and Environmental Microbiology 75: 7537-7541.

Schrag, D., J. Higgins, F. Macdonald \& D. Johnston, 2013. Authigenic carbonate and the history of the global carbon cycle. Science 339: 540-543.

Schuler, C., J. R. Havig \& T. L. Hamilton, 2017. Carbon fixation across geochemical gradients in the Greater Obsidian Pool Area. Frontiers in Earth Science. 5: 97.

Schwarz, J. I. K., W. Eckert \& R. Conrad, 2008. Response of methanogenic microbial community of a profundal lake sediment (Lake Kinneret, Israel) to algal deposition. Limnology and Oceanography 53: 113-121.

Seehausen, O., J. J. M. van Alphen \& E. Witte, 1997. Cichlid fish diversity threatened by eutrophication that curbs sexual selection. Science 277: 1808-1811.

Seitzinger, A., J. A. Harrison, J. K. Böhlke, A. F. Bouwman, R. Lowrance, B. Peterson, C. Tobias \& G. Van Drecht, 2006. Denitrification across landscapes and waterscapes: a synthesis. Ecological Applications 16: 2064-2090.
Smith, V. H. \& D. W. Schindler, 2009. Eutrophication science: where do we go from here? Trends in Ecology \& Evolution 24: 201-207.

Sophocleous, M., 2002. Interactions between groundwater and surface water: the state of the science. Hydrogeology Journal 10: 52-67.

Steffen, M. M., B. S. Belisle, S. B. Watson, G. L. Boyer \& S. W. Wilhelm, 2014. Status, causes and controls of cyanobacterial blooms in Lake Erie. Journal of Great Lakes Research 40: 215-225.

Strayer, D. L., 2009. Twenty years of zebra mussels: lessons from the mollusk that made headlines. Frontiers in Ecology and the Environment 7: 135-141.

Tranvik, L. J., J. A. Downing, J. B. Cotner, S. A. Loiselle, R. G. Striegl, T. J. Ballatore, P. Dillon, K. Finlay, K. Fortino, L. B. Knoll, P. L. Kortelainen, T. Kutser, S. Larsen, I. Laurion, D. M. Leech, S. L. McCallister, D. M. McKnight, J. M. Melack, E. Overholt, J. A. Porter, Y. Prairie, W. H. Renwick, F. Roland, B. S. Sherman, D. W. Schindler, S. Sobek, A. Tremblay, M. J. Vanni, A. M. Verschoor, E. von Wachenfeldt \& G. A. Weyhenmeyer, 2009. Lakes and reservoirs as regulators of carbon cycling and climate. Limnology and Oceanography 54: 2298-2314.

Van Dam, B. R., C. Tobias, A. Holbach, H. W. Paerl \& G. Zhu, 2018. $\mathrm{CO}_{2}$ limited conditions favor cyanobacteria in a hypereutrophic lake: an empirical and theoretical stable isotope study. Limnology and Oceanography 63: 1643-1659.

Vanderploeg, H. A., J. R. Liebig, W. W. Carmichael, M. A. Agy, T. H. Johengen, G. L. Fahnenstiel \& T. F. Nalepa, 2001. Zebra mussel (Dreissena polymorpha) selective filtration promoted toxic Microcystis blooms in Saginaw Bay (Lake Huron) and Lake Erie. Canadian Journal of Fisheries and Aquatic Sciences 58: 1208-1221.

Vanderploeg, H. A., T. F. Nalepa, D. J. Jude, E. L. Mills, K. T. Holeck, J. R. Liebig, I. A. Grigorovich \& H. Ojaveer, 2002. Dispersal and emerging ecological impacts of PontoCaspian species in the Laurentian Great Lakes. Canadian Journal of Fisheries and Aquatic Sciences 59: 1209-1228.

Wada, E., T. Kadonaga \& S. Matsuo, $1975 .{ }^{15} \mathrm{~N}$ abundance in nitrogen of naturally occurring substances and global assessment of denitrification from isotopic viewpoint. Geochemical Journal 9: 139-148.

Ward, C. P. \& R. M. Cory, 2016. Complete and partial photooxidation of dissolved organic matter draining permafrost soils. Environmental Science \& Technology 50: 3545-3553.

West, W. E., J. J. Coloso \& S. E. Jones, 2012. Effects of algal and terrestrial carbon on methane production rates and methanogen community structure in a temperate lake sediment. Freshwater Biology 57: 949-955.

Williamson, F. \& T. Ozersky, 2019. Lake characteristics, population properties and invasion history determine impact of invasive bivalves on lake nutrient dynamics. Ecosystems 22: 1721-1735.

Wolf, D. \& H. A. Klaiber, 2016. Bloom and Bust: Toxic Algae's Impact on Nearby Property Values. 2016 Agricultural \& Applied Economics Association Annual Meeting, Boston, Massachusetts.

Woodhouse, J. N., A. S. Kinsela, R. N. Collins, L. C. Bowling, G. L. Honeyman, J. K. Holliday \& B. A. Neilan, 2015. 
Microbial communities reflect temporal changes in cyanobacterial composition in a shallow ephemeral freshwater lake. The ISME Journal 10: 1337-1351.

Zhang, W., I. Lou, W. K. Ung, Y. Kong \& K. M. Mok, 2014. Application of PCR and real-time PCR for monitoring cyanobacteria, Microcystis spp. and Cylindrospermopsis raciborskii in Macau freshwater reservoir. Frontiers in Earth Science 8: 291-301.

Publisher's Note Springer Nature remains neutral with regard to jurisdictional claims in published maps and institutional affiliations. 